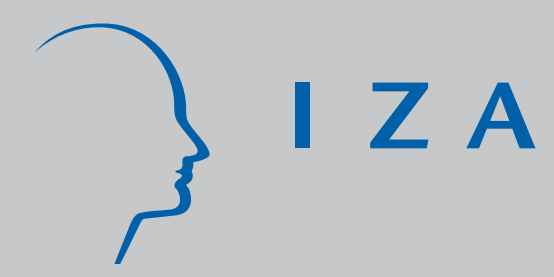

IZA DP No. 3735

What More Than Parental Income? An Exploration of What Swedish Siblings Get from Their Parents

Anders Björklund

Lena Lindahl

Matthew Lindquist

September 2008 


\title{
What More Than Parental Income? An Exploration of What Swedish Siblings Get from Their Parents
}

\author{
Anders Björklund \\ SOFI, Stockholm University \\ and IZA
}

Lena Lindahl

SOFI, Stockholm University

Matthew Lindquist

Stockholm University

Discussion Paper No. 3735
September 2008

IZA

P.O. Box 7240

53072 Bonn

Germany

Phone: +49-228-3894-0

Fax: +49-228-3894-180

E-mail: iza@iza.org

Any opinions expressed here are those of the author(s) and not those of IZA. Research published in this series may include views on policy, but the institute itself takes no institutional policy positions.

The Institute for the Study of Labor (IZA) in Bonn is a local and virtual international research center and a place of communication between science, politics and business. IZA is an independent nonprofit organization supported by Deutsche Post World Net. The center is associated with the University of Bonn and offers a stimulating research environment through its international network, workshops and conferences, data service, project support, research visits and doctoral program. IZA engages in (i) original and internationally competitive research in all fields of labor economics, (ii) development of policy concepts, and (iii) dissemination of research results and concepts to the interested public.

IZA Discussion Papers often represent preliminary work and are circulated to encourage discussion. Citation of such a paper should account for its provisional character. A revised version may be available directly from the author. 


\begin{abstract}
What More Than Parental Income? An Exploration of What Swedish Siblings Get from Their Parents*

Sibling correlations are used as overall measures of the impact of family background and community influences on individual outcomes. While most correlation studies show that siblings are quite similar in terms of future achievement, we lack specific knowledge of what it is about family background that really matters. Studies on intergenerational income mobility show that parental income matters to some extent, but they also show that more than half of the family background and community influences that siblings share are not even correlated with parental income. In this paper, we employ a data set that contains rich information about families in order to explore what factors in addition to parental income can explain why siblings tend to have such similar outcomes. Our results show that measures of family structure and social problems account for very little of sibling similarities in adult income above and beyond that already accounted for by parental income. However, when we add a set of indicators for parental involvement and attitudes, the explanatory power of all our variables increased from about a third (using only traditional indicators of socio-economic status) to just over half. Interestingly, indicators of parents' patience, i.e., propensity to plan ahead and willingness to postpone benefits to the future, are particularly important.
\end{abstract}

JEL Classification: D1, D3, J62

Keywords: family background, intergenerational mobility, parents, siblings, long-run income

Corresponding author:

Anders Björklund

SOFI

Stockholm University

SE-10691 Stockholm

Sweden

E-mail: anders@sofi.su.se

\footnotetext{
* We would like to thank Paul Devereux, Bhashkar Mazumder, John van Reenen, seminar and conference participants at London School of Economics, SOFI, University of Edinburgh and University of Zurich for valuable comments and suggestions. Björklund and Lindahl acknowledge financial support from the Swedish Council for Working Life and Social Research (FAS).
} 


\section{Introduction}

During the past 10 to 20 years, there has been an upsurge in empirical research by economists concerning the relationship between family background and income during adulthood. Most of this research has focused on the intergenerational relationship between parents' and offspring's long-run income and, most notably, the relationship between fathers' and sons' income. ${ }^{3}$ Many researchers motivate this type of work as a way of gauging the degree to which a society promotes equality of opportunity. Using Roemer's (1998) terminology, the argument is that family background represents "circumstances" that members of the offspring generation have not chosen themselves, in contrast to their own "effort". Thus, a strong dependence of outcomes, such as income during adulthood, on family background implies low equality of opportunity.

Given this motivation, it is somewhat surprising that relatively little research has been devoted to exploring sibling correlations in income. The literature on intergenerational mobility has recognized for quite some time that a correlation between siblings is, in fact, a broader measure of the importance of family background and community effects than the parent-offspring association. ${ }^{5}$ This is mainly due to the simple fact that siblings share much more than their parents' income. Your siblings represent a broad set of "circumstances" in life that you have not chosen yourself.

A sibling correlation in an outcome such as income has two properties that make it particularly informative and useful for a discussion about the importance of family background and community influences. First, from a simple decomposition of permanent income into a family and an individual component, it follows that a sibling correlation tells us what fraction of total inequality is attributable to the family and community component shared

\footnotetext{
${ }^{3}$ See Björklund \& Jäntti (2008) for a recent survey.

${ }^{4}$ See Bourguignon et al. (2007) for an illuminating empirical application of Roemer's (1998) approach.

${ }^{5}$ This insight goes back at least to Corcoran, Jencks \& Olneck (1976). See also Erikson (1987) and Sieben \& De Graaf (2003) for sociological approaches using occupational and educational variables. Solon (1999) offers a formal exposition of the interpretation of the sibling correlation and its relationship to intergenerational associations discussed here.
} 
by siblings. Second, the relationship between the sibling correlation in income and the corresponding intergenerational correlation (IGC) is as follows:

Sibling correlation $=(\mathrm{IGC})^{2}+$ other shared factors that are uncorrelated with parental income .

The few studies of sibling correlations in long-run income have estimated them to be around 0.45 for the United States and around 0.25 for the Nordic countries. ${ }^{6}$ Estimates of the IGC have centered around 0.4 for the United States and around 0.2 for the Nordic countries. Plugging these numbers into the above equation shows us that more than half of the family and community background influences that siblings share are not even correlated with parental income. The strong focus on intergenerational relationships in the current literature by economists is, therefore, like focusing only on the tip of the iceberg. There is much more below the surface that needs to be explored in order to understand the circumstances that are important for labor market achievement. The goal of this study is to fill some of this gap in the literature.

One reasonable hypothesis would be that it is neighborhood characteristics shared by siblings that dominate among the "other" shared factors that explain income. However, a few recent studies, covering Norway, Sweden and the United States, have all found that such factors are not very important. ${ }^{7}$ Therefore, it must be something within the family in addition to parental income that accounts for the relatively high sibling correlations in income. Investigating the contents of this "something" is what we intend to do in this paper. More

\footnotetext{
${ }^{6}$ See Solon et al. (1991) and Mazumder (2008) for US estimates and Björklund et al. (2002) for a comparative study of the US and the Nordic countries. Björklund, Jäntti \& Lindquist (2007) report recent Swedish estimates. ${ }^{7}$ See Raaum, Salvanes \& Sörensen (2006) for Norway, Solon, Page \& Duncan (2000), Page \& Solon (2003a, 2003b) for the United States, and Lindahl (2008b) for Sweden. The underlying idea in these studies (proposed by Solon, Page \& Duncan 2000) is that a correlation in adult outcomes among children who have grown up in the same neighborhood is an upper bound on the importance of factors that neighbours share. This upper bound, in turn, is found to be low compared to the sibling correlation that captures family as well as neighbour factors.
} 
specifically, we attempt to answer the following question: What more than parental income is responsible for generating positive and significant sibling correlations in income?

To do this, we make use of data from the Stockholm Birth Cohort Study (SBC). This data source contains a rich set of variables concerning individual, family, social and neighborhood characteristics. The data set includes all children who were born in 1953 and living in the greater Stockholm metropolitan area on November 1, 1963. Cohort members' siblings have been matched onto the data set along with income during adulthood. One feature of the SBC study that is particularly interesting for the problem at hand is that it includes survey data from interviews with the parents of the SBC cohort members. The Family Survey was conducted in 1968 and provides information about family structure, parental attitudes and child rearing strategies.

The remainder of the paper is structured as follows: In Section 2, we offer a more detailed explanation of what a sibling correlation is (and isn't) and explain how it can be estimated. We also describe our econometric approach to disentangling the determinants of this correlation. Section 3 contains a discussion of previous related studies, which guide us in our search for explanatory variables. Section 4 describes the data source in more detail. Our baseline empirical results are reported in Section 5, which is followed by a series of sensitivity analyses in Section 6. We conclude, in Section 7, with a summary and brief discussion.

\section{Exploring Sibling Correlations: Models and Methods}

To clarify the useful interpretation of the sibling correlation, suppose that we have an outcome measure such as long-run income at our disposal. This variable, $y_{i j}$, for sibling $j$ in family $i$ can be modeled as 
(1)

$$
y_{i j}=\mu+\varepsilon_{i j}
$$

where $\mu$ is the population mean and $\varepsilon_{i j}$ is an individual-specific component with population variance $\sigma_{\varepsilon}^{2}$. The individual component represents the individual's position in the long-run income distribution, which is what we want to focus our attention on. It can be viewed as the sum of two components

$$
\varepsilon_{i j}=a_{i}+b_{i j}
$$

where $a_{i}$ is a permanent component common to all siblings in family $i$, and $b_{i j}$ is a permanent component unique to individual $j$ in family $i$, which captures individual deviations from the family component. The two components are independent by construction. Thus, the variance of $\varepsilon_{i j}$ is the sum of the variances of the family and individual components:

$$
\sigma_{\varepsilon}^{2}=\sigma_{a}^{2}+\sigma_{b}^{2}
$$

The share of the variance in the outcome variable, $y_{i j}$, which can be attributed to family background effects, is

$$
\rho=\frac{\sigma_{a}^{2}}{\sigma_{a}^{2}+\sigma_{b}^{2}} .
$$

This share coincides with the correlation in the outcome variable of randomly drawn pairs of siblings, which is why $\rho$ is called a sibling correlation. 
A sibling correlation can thus be thought of as an omnibus measure of the importance of family background and community effects. It includes anything shared by siblings: parental income and parental influences such as aspirations and cultural inheritance, as well as things not directly experienced in the home, such as school, church and neighborhood effects. Genetic traits not shared by siblings, differential treatment of siblings, time-dependent changes in neighborhoods, schools, etc. are captured by the individual component $b_{i j}$. If such non-shared factors are relatively more important than shared factors for incomes, the variance of the family effects will be small relative to the variance of the individual effects and the sibling correlation will be low. The more important the effects that siblings share are, the larger is the sibling correlation.

In order to calculate the sibling correlation in long-run income, $\rho$, we need estimates of the within-family variation, $\sigma_{b}^{2}$, and the between-family variation, $\sigma_{\mathrm{a}}^{2}$. These are obtained using the following mixed-effects model

$$
y_{i j}=\mathbf{x}_{i j} \boldsymbol{\beta}+a_{i}+b_{i j}
$$

where $a_{i} \sim N\left(0, \sigma_{\mathrm{a}}^{2}\right)$ and $b_{i j} \sim N\left(0, \sigma_{\mathrm{b}}^{2}\right)$. This formulation allows for the inclusion of multiple control variables $\mathbf{x}_{i j}$; the $\boldsymbol{\beta}$ 's are considered fixed effects. The matrix $\mathbf{x}_{i j}$ includes a third-order polynomial in age in order to control for a deterministic age-income profile, reflecting the fact that siblings of different ages may find themselves at different points in their life-cycle income profile. Such a model is the prototypical one used in the previous studies of sibling correlations discussed in the introduction. A minor exception is that we directly use a measure of long-run income, whereas most previous studies employ annual income and therefore sometimes add a transitory error component to model (8). 
Our contribution in this paper is to include potentially important family-wide variables, either one at a time or simultaneously, in the $\mathbf{x}_{i j}$ matrix. For example, consider the inclusion of parental income in $\mathbf{x}_{i j}$. This additional control variable should reduce the residual variation in the outcome variable and produce a lower estimate of the between-family variation, $\sigma_{\mathrm{a}}{ }^{2 *}$, than the estimate produced without the added control for parental income. We interpret the difference between these two estimates, $\sigma_{a}^{2}-\sigma_{a}{ }^{2 *}$, as an upper bound on the amount of the variance in the family component that can be explained by parental income. It is viewed as an upper bound on the importance of parental income, since it includes other factors that are correlated with parental income. This experiment also produces a new sibling correlation $\rho^{*}$. From what we know about the relationship between intergenerational and sibling correlations, we expect this new sibling correlation to be lower, but still substantial in magnitude.

The central question that we address in this paper is: What more than parental income matters for adult outcomes? To answer this question, we continue adding variables to the $\mathbf{x}_{i j}$ matrix in order to produce new estimates of the between-family variation, $\sigma_{\mathrm{a}}{ }^{2 * *}$. We interpret the difference between $\sigma_{\mathrm{a}}{ }^{2 * *}-\sigma_{\mathrm{a}}{ }^{2 *}$ as the added importance of the new variable(s) above and beyond that already accounted for by parental income. ${ }^{8}$ We now turn to a discussion of previous literature that can guide us in the search for such variables.

\section{Previous Literature and Our Choice of Family-Wide Variables}

The challenge is to find family background characteristics that can account for sibling similarities above those created by parental income. Because most favorable parental characteristics that have an impact on children's income also likely affect parents' own

\footnotetext{
${ }^{8}$ Mazumder (2008) has inspired us to pursue this approach. He adds a two-year average of parental income as one additional variable and finds a 36 percent reduction of the sibling correlation. Then he also adds nonmonetary characteristics of various types, but these are all variables pertaining to the offspring (the siblings). Our interpretation that the addition of offspring variables in the $\mathbf{x}_{i j}$ matrix addresses a different question than the one we are interested in. Mazumder's approach sheds light on the question via which variables parental income has an impact, whereas our approach explores the question what parental characteristics are important for siblings' outcomes.
} 
income, it is hard to say a priori what characteristics are particularly important. This fact also underscores the exploratory nature of our investigation.

One basic group of potentially important variables can be labeled family structure. It is well known that variables such as parental separation, number of siblings and mother's age at birth are strong correlates of the child's achievement during adulthood. Interestingly, Fryer Jr. and Levitt (2004), in their search for variables that can explain black-white differences in early test scores in the United States, find that such variables have explanatory power even conditional upon the socio-economic status of the parents. One objection to using parental separation in a study like ours could be that it affects children differently, so that an older sibling who has left home when the separation occurs is less affected by the separation, whereas a younger sibling who more directly experiences the separation is significantly affected. However, there is a growing consensus in the literature that parental separation is correlated with child outcomes not in the first place due to causal effects, but by serving as an indicator of underlying characteristics that predict weak outcomes. ${ }^{9}$ Out data set - to be presented in the next section - offers a number of such family structure variables that we will explore.

One could also argue that a standard measure of parental income, or even a broader measure of parents' socioeconomic status, does not fully capture the intergenerational impact of a set of social problems that some families suffer from. Variables such as social assistance recipiency, drug and alcohol abuse, mental illness and father's criminality are generally found to be intergenerationally connected. ${ }^{10}$ Such variables might serve as indicators of underlying characteristics that have negative effects on offspring's labor market achievement. The intergenerational association might also reflect causal effects of the specific characteristic; for example via role modeling parents' social recipiency or criminal behavior might affect their

\footnotetext{
${ }^{9}$ See, e.g., Ginther \& Pollak (2004) for U.S. evidence and Björklund \& Sundström (2006) for Swedish evidence.

${ }^{10}$ See, for example, Case \& Katz (1991) and Duncan et al. (2005) for U.S. evidence. Hjalmarsson \& Lindquist (2007) find strong intergenerational patterns in criminality using the same Swedish data set as we use.
} 
children directly. Such behavior, in turn, may have deleterious effects on income during adulthood. We include a set of such social problem indicators in our analysis.

A third group of variables that are reasonable to explore for our purposes refer to parenting style. Most likely some styles of parenting are more conducive to children's labor market success than others. Duncan et al. (2005) offers an interesting general discussion of the intergenerational implications of parenting styles, a discussion that is based on insights from development psychology. Their US data set allows them to consider five parenting practices denoted as parental involvement, parental monitoring, child autonomy, emotional warmth and child stimulation. But much to their surprise, such indicators are generally insignificant, or at least not very important, in explaining a number of different child outcomes. Fryer Jr. and Levitt (2004) also experiment with some parenting indicators such as the use of spanking. They do not find any strong intergenerational impact of such parenting indicators. Nevertheless, we find it useful to consider such variables in our exploration of Swedish data. We employ a set of questions that we call parenting firmness and another set of questions that we call parental involvement in school work.

Parents can also help and influence their children by offering a home environment that is conducive to school performance and further learning. A concrete example is to keep useful books available in the home. Many surveys include a question about how many books are available in the home. Both Fryer Jr. \& Levitt (2004) and Mason (2007) find significant coefficients for such a variable in explaining child outcomes. Although the causal interpretation of these results is unclear, we include a variable called number of books in the home in our analysis.

Finally, children are likely to inherit family values of different types that are more or less conducive to labor market success. In an interesting study, Dohmen et al. (2006) employ German intergenerational data and demonstrate quite strong parent-child associations in 
willingness to take risks and willingness to trust other people. Their measures of risk and trust are validated in several ways. For example, they plug one of their risk measures into a standard Mincer earnings equation and find that wages are 20 percent higher for those who are fully prepared to take risks than those who are completely unwilling to do so (on their 11point scale). They do not set up a statistical horse-race between income (or socio-economic status) variables and their family value variables. Therefore, one cannot rule out that the intergenerational risk and trust associations that they find mainly capture the same mechanisms as an intergenerational income association would capture. However, Mason (2007) using related but not as coherent family-value indicators (for the US), find that they are significant also in equations with parental socio-economic status variables included. We would have preferred to have the same type of risk and trust variables as Dohmen et al. (2006) at our disposal but unfortunately our data source does not contain this information. We have, however, identified a set of questions that are somewhat related to Dohmen et al.'s (2006) risk questions, namely questions about the willingness to postpone financial gains into the future. We call this set of indicators parental patience.

\section{Data}

Our data come from the Stockholm Birth Cohort (SBC), which was created in 2004/2005 by means of a probability matching of two previously existing longitudinal datasets. ${ }^{11}$ The first is the Stockholm Metropolitan Study 1953-1985 (SMS), which consists of all children born in 1953 who were living in the Stockholm metropolitan area on November 1, 1963. This study contains a rich set of variables concerning individual, family, social and neighborhood characteristics. The second is The Swedish Work and Mortality Database (WMD), which consists of administrative register information on income, work, unemployment, in-patient

\footnotetext{
${ }^{11}$ See Stenberg and Vågerö (2006) for a full description of the dataset and the matching procedure. Codebooks describing all of the data are available upon request and will soon be made available online.
} 
and mortality data for all individuals living in Sweden in 1980 or 1990 who were born before 1985.

Data from the WMD for the years 1990 - 2001 were matched onto data from the SMS. These data include information on income, which is the object of interest in this study. The outcome variable that we want to "explain" is the sibling correlation in long-run income. Our measure of long-run income is the log of average annual labor market income for the years 1990 - 2001. Annual labor market income comes from registers based on employers' compulsory reports to the tax authorities. It includes sickness benefits, parental leave benefits and income from self employment (including farming). It excludes capital income, pensions, unemployment benefits and social assistance. Average labor market income is calculated using only those positive income years that exceed 10,000 SEK in 2001 prices (approximately 1,400 USD). In Section 6, we examine how sensitive our main findings are to this particular treatment of low, zero and missing incomes.

The Stockholm Birth Cohort dataset also includes income data from the WMD for all siblings to the original SMS cohort members. This is what allows us to calculate sibling correlations in long-run income. Siblings of the original SMS cohort members were identified using Statistic Sweden's Multi-Generational Register. Cohort members and siblings are identified through their mother, which means that the data include biological siblings as well as half-siblings on the mother's side. The data also include children that are adopted by the mother. Unfortunately, we cannot distinguish between half-siblings and adopted children from full biological siblings in this particular dataset.

When calculating sibling correlations in income, we only use data for closely spaced siblings, since we believe that siblings that are close in age probably experience more similar childhoods than siblings with large age differences. Since most of our explanatory variables were collected with the original SMS cohort member in mind, we centre the age of older and 
younger siblings on the SMS cohort members' age (who were all born in 1953). The youngest siblings are born in 1956 and the oldest are born in 1950. Thus, the maximum possible age difference between any pair of siblings is 7 years. In Section 6, we study how sensitive our main findings are to changes in these age limits. ${ }^{12}$

Once we have our sibling correlation in long-run income in hand, the goal of this study is to see how much of the family component (i.e., what siblings share) can be explained, or accounted for, by adding in a series of control variables to our $\mathbf{x}_{i j}$ matrix. We examine the importance of seven different categories of control variables: (1) parental income (and other traditional measures of socio-economic status), (2) family structure, (3) social problems, (4) parenting firmness, (5) parental involvement in schoolwork, (6) number of books in the home, and (7) parental patience. We also allow for neighborhood fixed effects. All of the variables in each one of these categories are taken from the original Stockholm Metropolitan Study. Descriptive statistics for all variables included in categories (1) - (3) are presented in Table 1. Variables in categories (5) - (7) are presented in Table 2.

Our traditional measures of parental socio-economic status include both the father's and the mother's total market income in 1963. These were taken from the official tax register. We would have preferred to use a measure of long-run income, but instead we add parental education and occupation data to come closer to a long-run measure of income. We have information on the education of both parents taken from the 1960 census. ${ }^{13}$ Education is given by 3 categories: (1) grade school, (2) high school and (3) college. We also include a variable for the father's occupational category in 1953 and 1963. This measure is collapsed into 5

\footnotetext{
${ }^{12}$ Since we have income data for the years 1990 - 2001, our age limits imply that we observe income for ages 34 - 51. According to Böhlmark \& Lindquist (2006), this means that our measure of long-run income is appropriate for the women in the sample, but that it is probably too high for the men in our sample given that we want to mimic lifetime income. For men, one would prefer to have it centered around (or, at least, closer to) age 34 . However, since we are dealing with closely spaced brothers, this bias should be roughly equal for both. This potential life-cycle bias may affect the level of our baseline correlation (slightly), but it should not affect our efforts towards explaining sibling correlations using a set of common family background variables.

${ }^{13}$ Note that 960 of the original 15,117 SMS cohort members (6.4 percent) were not included in, or did not respond to, the 1960 census. Thus, any variables taken from this census (e.g., parental education) are missing for these 960 individuals.
} 
strata: (1) upper and upper middle class, (2) lower middle class officials and non-agricultural employees, (3) lower middle class, entrepreneurs, (4) working class, skilled workers and (5) working class, unskilled workers. Missing values for this variable tend to be strong predictors of negative outcomes, so we include missing as a separate stratum. ${ }^{14}$

Since we are interested in studying the importance of what families give their children and not in the impact of neighborhoods, local school quality, etc. (i.e., other things that siblings may share), we include controls for neighborhood fixed-effects. Neighborhoods are defined in terms of the family's place of residence in $1963 .{ }^{15}$ By controlling for neighborhood fixed-effects, the sibling correlation that we explain becomes a "tighter upper bound" on the importance of common family background variables (see, e.g., Page \& Solon (2003a) or Raaum et al. (2006) for more discussion). However, if sorting into neighborhoods by income and education is important, then we may, actually, be controlling for some of what we would (instead) like to explain.

Our second category of "exploratory" variables, family structure, includes the mother's age at the birth of her first child and the total number of children in the family (number of siblings). We also include two variables that are meant to reflect the type of family that our siblings grew up in. The first of these variables is concerned with the marital status of the head of the household and is taken from the 1960 census. This variable includes 5 categories: (1) married, not cohabitating, (2) married and cohabitating, (3) single, (4) widow/widower, and (5) divorced. The second variable is taken from the 1964 register of population and income and refers to the family type in 1963: (1) father and mother living together, (2) mother

\footnotetext{
${ }^{14}$ Missing is because the father was unemployed, in jail, or for some other reason could not be categorized. When the father was missing altogether from the family, information on the mother's occupational status was used instead.

${ }^{15}$ The neighborhood classification we use was constructed by Statistics Sweden using the necessary census, housing and population registers. Their intention was to make neighborhoods as homogeneous as possible. For example, the neighborhood areas were designed to include the same kind of housing such as high-rise blocks or residential districts with owner occupied housing. They tried to separate areas of apartment houses from residential districts, densely populated areas from sparsely populated areas, etc. The classification was also based, in part, on the age and general economic standard of the buildings.
} 
living alone, (3) father living alone, (4) mother living together with other than child's biological father, (5) father living together with other than child's biological mother, and (6) other.

Our variables indicating social problems include an indicator whether the family received any social assistance (welfare payments) during the period $1953-1972 .{ }^{16}$ We have information on "incidents of drunkenness" and alcoholism for both parents. Furthermore, we have knowledge about serious mental health problems of either parent and also if either parent died before 1972. All of these variables are taken directly from the files of the original SMS cohort members kept by the local Child Welfare Committees. We code them as dummies: yes $=1$ and no $=0$. Lastly, we have official police register data concerning the number and type of the fathers' criminal convictions (if any).

Besides the data mentioned above, which are sourced from official census and/or register data, the original Stockholm Metropolitan Study also consisted of various separate surveys. In this paper, we make use of information taken from the Family Study conducted in 1968, which includes information on (among other things) parental involvement with schoolwork, parenting styles and firmness, and parental attitudes such as patience.

The Family Study was conducted in the following manner: In 1968, a sample of the cohort members' mothers (or substitute mothers) was interviewed. Of the original 15,117 SMS cohort members, 4,021 were included in the sample that was interviewed for the Family

\footnotetext{
${ }^{16}$ It is important to note that, unlike welfare in the United States, means-tested social support in Sweden is not primarily aimed at single-mothers. In Sweden, all single-parents receive support through a system of family support that is (for the most part) not means-tested. Furthermore, we could have included means-tested social support as an indicator of socio-economic status. But we believe that it is a better signal of social problems than of long-run socio-economic status. Our reasoning follows that of Stenberg (2000) who has studied the inheritance of welfare recipiency between generations using the SBC data. He argues that, "Because the main part of Swedish social benefits is universal, families who fall through this economic safety net and must rely on means-tested assistance as their last resort are likely to be a more negatively selected group with respect to different types of social problems. Therefore, we could expect to find a greater representation of non-economic problems here than among welfare families in the United States (p. 233)." Hjalmarsson \& Lindquist (2008) report that the five strongest predictors of receiving social support in the original SMS cohort data are (in order of their importance); psychological problems of parents, alcoholism of parents, single household (predominantly single mothers), "incidents" of drunkenness by the mother and father's criminality.
} 
Study. ${ }^{17}$ This sample, however, was not drawn randomly. First, the SMS cohort members that were still living in the greater Stockholm metropolitan area as of November 1, 1967 were listed. Some 525 original cohort members had been lost since November 1, 1963. The mental test scores (from the 1966 School Study) of the remaining 14,592 were placed into five groups: (1) high, (2) medium, (3) low, (4) non-response and (5) incomplete. All cohort members in the "high" group were kept in the sample. High was defined as the top 5 percent of scores. All cohort members in the "low" group were also kept. Low was defined as the lowest 5 percent of the scores. The cut-off points for high and low were set separately for boys and girls. In each of the other 3 groups, one in five cohort members was chosen at random. Of these 4021 cohort members, 370 chose not to participate, so 3651 persons are included in the Family Study sample.

In this study, we use this sample of individuals, together with their siblings, in our preferred estimations, since we feel that the types of questions asked and information collected in this particular survey fit our research purpose. Table 1 gives us some feel for just how selected (non-representative) this sample actually is. What we find is that the smaller, family study sample is (for all practical intents and purposes) perfectly representative of the full sample. There is no variable, neither individual nor family-wide, for which the descriptive statistics for the family sample differ from those of the full sample in any meaningful way. Despite this, we also run all of our estimates on the full sample, whenever possible. That way we can compare nearly all of our results using the smaller sample with those found using the full sample. We also compare our baseline results to those using a somewhat smaller, but perfectly random, version of the Family Survey sample. This sensitivity analyses is done in Section 6.

\footnotetext{
${ }^{17} 1,972$ females and 2,049 males.
} 
The rest of our family-wide variables are taken from the Family Study. First, we use a set of questions concerned with parental involvement in schoolwork. The interviewers asked a series of questions of each mother (or substitute mother) including, for example; Do you and your daughter/son ever talk about what she/he has read/done in school? Mothers could choose from the following answers: (1) very often, (2) rather often, (3) now and then, (4) rather seldom, (5) almost never, or (6) do not know. Mothers were then asked to answer the same set of questions terms of their husband's involvement in their child's schoolwork. The full set of questions and answers is listed in Table 2 .

The second set of questions that we make use of deal with parenting firmness, which is intended to reflect a particular parenting style. Mothers were asked whether or not they agreed with a set of statements, for example; Children must have firm rules. Mothers were allowed to choose from the following answers: (1) quite right, (2) generally, right, (3) neither right nor wrong, (4) generally, wrong, (5) quite wrong, or (6) do not know. The full list of statements that we make use of is reported in Table 2 along with the mothers' answers.

We also make use of a set of questions about the future. We view these questions as a measure of parental patience. Mothers were asked a series of questions, for example; If you could choose between 1,000 SEK now and 10,000 SEK in five years, would you choose 1,000 SEK now? The answers that they could choose from were: (1) yes, definitely, (2) yes, perhaps, (3) do not know, (4) no, perhaps not, or (5) no, definitely not. Table 2 reports the full set of questions along with the mothers' answers.

The last question that we use is the (now) classic book question: How many books do you think there are in this apartment/house? The possible answers and the responses are shown in Table 2.

\section{Results}


We begin by considering our estimated sibling correlations with controls only for siblings' age. The upper panels of Table 3A (the Family Survey sample) and 3B (the full sample) report these estimates for men and women separately and pooled, where pooling allows us to also include mixed gender siblings in the identification of our two variance components. The pooled estimates are $0.215(0.022)$ and $0.190(0.012)$ for the Family Survey sample and the full sample, respectively. ${ }^{18}$ These estimates are quite similar in magnitude to each other and also to previous estimates cited in our introduction. The brother correlations are $0.221(0.042)$ and $0.267(0.022)$, respectively. Our sister correlations are $0.248(0.040)$ and $0.168(0.021)$ for the Family Survey and full samples, respectively. Although our two sister estimates are significantly different from each other at the 10 percent level, it remains to be seen how, if at all, this will affect our experiment. Since our goal is to account for the determinants of our sibling correlations, this difference need not be problematic per se.

In the lower panels of Tables $3 \mathrm{~A}$ and $3 \mathrm{~B}$, we add neighborhood dummies, parental income, parental education and the father's socio-economic status to our $\mathbf{x}_{i j}$ matrix. We first add each variable separately in order to explore their individual importance and then we add all of the variables simultaneously. For brothers, father's income, education and socioeconomic status matter most. For sisters in the Family Survey sample, father's socioeconomic status and (surprisingly) neighborhood effects appear to matter most. But in the full sample, no single variable seems to reduce the family variance component (or the sister correlation) by any large amount. ${ }^{19}$ Pooled effects match those for brothers quite closely.

So how much of the family variance component (and sibling correlation) can we account for when we control for all of these variables at once? Once we do this, we can account for 43 percent (37 percent) of the family variance component (sibling correlation) for

\footnotetext{
${ }^{18}$ Numbers in parentheses are approximate standard errors calculated with the delta method using the $n l c o m$ command in STATA.

${ }^{19}$ We have chosen to focus on percentage decreases of 10 percent or more. This is what we mean by "large". An alternative to this would be to focus on statistically significant reductions in the family component and/or sibling correlation.
} 
brothers and 28 percent ( 24 percent) for sisters in the Family Survey sample. In the full sample, these numbers are reduced to 26 percent (21 percent) and 19 percent (16 percent), respectively. These magnitudes of the importance of parental income determinants are in line with what would be expected from previous estimates of sibling correlations and intergenerational correlations according to the formal relationship between these parameters stressed in the introduction. Note also that Mazumder (2008) found a 36 percent reduction in the family variance component after adding a two-year average of parental income.

We now turn to the basic question addressed by our study: What more than parental income do siblings get from their parents? Tables $4 \mathrm{~A}$ and $4 \mathrm{~B}$ contain the results we obtain when adding our indicators for family structure. Both samples tell the same story. Mothers' age at first birth (entered with a flexible functional form) is the single most important variable. But it only appears to be quantitatively important for brothers. The number of siblings in the family does not seem to matter much, which is in line with the findings in Lindahl (2008a). Taken together, our family structure variables account for about half of what the indicators of long-run income (in Tables 3A and 3B) accounted for. However, if we examine the bottom rows in Tables 4A and 4B (labeled All Controls Used in Tables 3 and 4), we see that the total amount of variation explained in addition to the variation already accounted for by parental income is quite small. For our pooled sample of men and women, the percentage of the sibling correlation that we can account for goes up from 31 to 35 percent in the Family Survey sample and from 22 to 26 percent in the full sample. Looking at brother and sister correlations separately reveals a similarly small increase. These results suggest that family structure and the income indicators to a large extent capture the same underlying mechanisms

Next, in Tables 5A and 5B, we explore the impact of our indicators of social problems. Social Support is the single most important indicator. But the total reduction of the sibling 
correlation from all these variables is somewhat lower than the corresponding reduction of the family structure variables. Furthermore, the additional explanatory power, above and beyond those variables that we have already included, is negligible in both samples.

Finally, we add the variables for parental involvement and attitudes, which are only available for the Family Survey sample. Table 6 shows these results. It is interesting to note that these variables (when added simultaneously) can account for reductions in both the family variance component and the sibling correlation of the same magnitude as our indicators of long-run income shown in Table 3A.

The set of indicators that is most important is the one that capture parental patience, closely followed by the number of books in the home. For women, parental patience is the single most important variable included in this study! This may, in part, be due to the fact that it is actually mothers' attitudes about the future (her patience) that we are measuring. Do you like to make long term plans? is the question that appears to matter most. Maternal patience is correlated with her education and the education and income of her spouse, but it also has a predictive value for her children's incomes independent of these factors. ${ }^{20}$

Parental involvement in schoolwork and parenting firmness are of second order importance, which is quite interesting given the large emphasis usually placed on these two factors by parents and experts alike when discussing "good" parenting practices. These results are in line with the previous findings of Duncan et al. (2005) and Fryer Jr. and Levitt (2004) concerning parenting styles and parenting practices. Neither of these earlier studies reports direct evidence of the importance of such factors for children's outcomes.

The bottom rows of Table 6 show that the total reduction in the family variation component is between 54 and 57 percent. This accounts for 48 to 51 percent of the sibling correlation in the Family Survey sample. This implies that more than half of the iceberg (that

\footnotetext{
${ }^{20}$ Mothers' incomes are negatively correlated with fathers' incomes and can not be predicted by maternal patience. We do not have a good measure of wealth. But we do have a measure of capital income in 1963 for both the mother and the father. Neither of these are correlated with maternal patience.
} 
we alluded to in our introduction) can now be viewed from above the surface. In addition to parental income, we have also discovered that your mother's age at first birth, whether or not your parents received social support when you were young, your parent's willingness to postpone financial gains and plan for the future (i.e., their patience), and the number of books in your home, are all factors that (somehow) work to make you and your siblings more similar in terms of your adult income.

\section{Sensitivity analysis}

Our baseline specification and sample definition involve a number of choices. In this section, we investigate the robustness of our main findings to several of these potentially important choices. For example, all sibling correlations in income are estimated using data for siblings born between 1950 and 1956, i.e., the maximum possible age difference between any pair of siblings is 7 years. In order to see how sensitive our main findings are to changes in this age limit, we first expand the maximum age limit to 8 years and then contract it to 6 years. Changes in the allowable age spread have little impact on our results.

Next, we perform a sensitivity analysis to check if our treatment of low, zero and missing incomes is important for our results. In our baseline specification, we have calculated income averages using only those years in which income exceeds 10,000 SEK in 2001 prices. Here, we drop the income restriction and include all income years in the averages (missing are treated as zeros, so that all individuals now have 12 income years). As expected, dropping the income restriction affects the sibling correlation estimates: For brothers the correlation drops from 0.22 to 0.14 . In this experiment, our complete set of variables decreases the family variance component by 44 percent in the Family Survey sample, as opposed to 57 percent in our preferred specification. 
Note that both the family and the individual variance component rise substantially, but the individual component rises by more. This is what lowers the sibling correlation from 0.22 to 0.14 . This implies that zero incomes and missing incomes are not clustered within families. So, we are not throwing away information about families by imposing a positive annual income requirement of 10,000 SEK (in 2001 prices).

Our last sensitivity analysis deals with the non-random construction of the Family Survey sample. Recall that the sample includes all of those in the top 5 percent and bottom 5 percent of the IQ test score distribution, taken from the 1966 School Study. A 20 percent random sample of the remaining children were then included in the Family Survey. Although we already saw in Tables 1 and 2 that the Family Survey sample and the full sample are observationally equivalent, we still would like to see if the non-randomness of the sample affects our results. What if, for example, all of the action is in the upper and/or lower tails of the ability distribution?

We perform this sensitivity analysis by simply throwing out 4 out of 5 cohort members belonging to the "high" stratum and the "low" stratum (of course, we throw out their brothers and sisters too). We let the computer do this for us in pseudo-random manner. This lowers the Family Survey sample size from 8719 individuals to 6301. The new (old) sibling correlations for men are $0.219(0.221)$. For women they are $0.240(0.248)$ and for pooled they are 0.215 $(0.215)$

This does affect some of our results. For example, in Tables $3 \mathrm{~A}$ and $3 \mathrm{~B}$ we saw that neighborhood effects tended to matter for women in the Family Survey sample, but not for women in the full sample. Also father's SES was more important for both men and women in the Family Survey sample than in the full sample. These differences do not survive once we weight down the tails of the ability distribution (by throwing out 4 out of 5 high and low ability students). The same holds true for our results concerning mother's age at first birth and 
receipt of social support. The variance reductions were larger in the Family Survey sample than in the full sample and this difference disappears once we re-weight the Family Survey sample.

This means two things. First, it means that, in general, our full sample results are more reliable. Second, this implies that there is extra action going on in the tails of the ability distribution. But it also raises an important question: Are the results in Table 6 inflated by the non-representative nature of the Family Survey sample? The answer to this question is no. The importance of parental involvement in schoolwork and parental patience are actually somewhat higher when using the re-weighted Family Survey sample.

\section{Conclusions}

We have explored what lies behind sibling correlations in long-run income. As in previous Swedish studies, we estimated such correlations to be around 0.22 . From the interpretation of a sibling correlation it then follows that 22 percent of the variation in long-run income can be attributed to factors that siblings share. In conformity with previous studies of intergenerational correlations in long-run income, we also found that parental income at most can account for between one quarter and one third of this 22 percent. Neighborhood indicators did not change these numbers by very much, which is also a result that is in line with previous results.

Our contribution has been to explore whether family characteristics other than parental income can (statistically) explain more of these family background effects. We first added quite rich sets of indicators for family structure and social problems, but (overall) these added variables account for very little of sibling similarities in adult income above and beyond that already accounted for by parental income. Mother's age at first birth and the family's receipt 
of social support do appear to matter somewhat, but their importance appears confounded with that of parental income.

When we added a set of indicators for parental involvement and attitudes, the explanatory power of our set of family-wide variables increased from about a third (with only indicators of long-run income and neighborhoods) to just over half. Interestingly, indicators of parents' patience, i.e., willingness to postpone benefits into the future and propensity to plan ahead, proved to be particularly important. While these results give some guidance for researchers to investigate the role of parental attitudes in more detail, it is hard to see the direct policy implications. Affecting parental attitudes is not an easy task for politicians.

Although we have had a rich data set at our disposal, future research would benefit from surveys that measure variables such as parental patience and risk attitudes with greater precision. It would also be useful with data that measure parental attitudes at different occasions and separately for each child (sibling). Finally, finding sources of exogenous variation in our exploratory variables is necessary for causal inference about what more than parental income is important for child outcomes.

\section{References}

Björklund, A., T. Eriksson, M. Jäntti, O. Raaum and E. Österbacka (2002) "Brother Correlations in Denmark, Finland, Norway and Sweden Compared to the United States," Journal of Population Economics 15(4), 757-72.

Björklund, Anders and Markus Jäntti (2008) "Intergenerational Income Mobility and the Role of Family Background," forthcoming in Oxford Handbook of Economic Inequality, Oxford University Press.

Björklund, Anders, Markus Jäntti and Matthew J. Lindquist (2007) "Family Background and Income during the Rise of the Welfare State: Brother Correlations in Income for Swedish Men Born 1932 - 1968," IZA DP 3000.

Björklund Anders and Marianne Sundström (2006) "Parental Separation and Children's Educational Attainment: A Siblings Analysis on Swedish Register Data," Economica November, 606-24. 
Böhlmark, Anders and Matthew J. Lindquist (2006) "Life-Cycle Variation in the Association between Current and Lifetime Income: Replication and Extension for Sweden," Journal of Labor Economics 24(4), 879-96.

Bourguignon Francois, Francesco H. G. Ferreira and Marta Menéndez (2007) "Inequality of Opportunity in Brazil," Review of Income and Wealth 53(4), 585-618.

Case Anne and Lawrence Katz (1991) "The Company You Keep: The Effects of Family and Neighborhood on Disadvantaged Youth,” NBER WP 3705.

Corcoran, M., C. Jencks and M. Olneck (1976) "The Effects of Family Background on Earnings," American Economic Review 66(2), 430-35.

Dohmen, Thomas, Armin Falk, David Huffman and Uwe Sunde (2006) "The Intergenerational Transmission of Risk and Trust Attitudes,” IZA DP 2380.

Duncan, Greg, Ariel Kalil, Susan E. Mayer, Robin Tepper and Monique R. Payne (2005) "The Apple Does Not Fall Far from the Tree," in Bowles, Gintis \& Groves (eds.), Unequal Chances, Princeton University Press.

Erikson, Robert (1987) "The Long Arm of the Origin: The Effects of Family Background oon Occupational and Educational Achievement," in Bergryd \& Janson (eds.) Sociological Miscellany, University of Stockholm.

Fryer Jr., Robert G. and Steven D. Levitt (2004) "Understanding the Black-White Test Score Gap in the First Two years of School," The Review of Economics and Statistics 86(2), 447-64.

Ginther, Donna and Robert Pollak (2004) "Family Structure and Children's Educational Outcomes: Blended Families, Stylized Facts, and Descriptive Regressions," Demography 41(4), 671-96.

Hjalmarsson, Randi and Matthew J. Lindquist (2008) "Like Godfather, Like Son: Explaining the Intergenerational Nature of Crime," Department of Economics, Stockholm University.

Lindahl, Lena (2008a) "Do birth order and family size matter for intergenerational income mobility? Evidence from Sweden," Applied Economics, 40(17): 2239-57.

Lindahl, Lena (2008b) "A Comparison of Family and Neighborhood Effects on Grades, Test Scores, Educational Attainment and Income - New Evidence for Sweden," manuscript, Swedish Institute for Social Research, Stockholm University.

Mason Patrick L. (2007) "Intergenerational Mobility and Interracial Inequality: The Return to Family Values," Industrial Relations 46(4), 51-80.

Mazumder, Bhashkar (2008) "Sibling Similarities and Economic Inequality in the U.S.," Journal of Population Economics 21, 685-701.

Page, M. E. and G. Solon (2003a) "Correlations between Brothers and Neighboring Boys in Their Adult Earnings: The Importance of Being Urban,” Journal of Labor Economics 21(4), 831-55. 
Page M. E. and G. Solon (2003b) "Correlations between Sisters and Neighboring Girls in Their Subsequent Income as Adults,", Journal of Applied Econometrics 18, 545-62.

Raaum, O., K.-G. Salvanes and E. Sørensen (2006) "The Neighborhood Is Not What It Used to Be," Economic Journal 116(1), 200-22.

Roemer, John E. (1998) Equality of Opportunity, Harvard University Press, Cambridge, MA.

Sieben Inge and Paul M. De Graaf (2003) "The Total Impact of the Family on Educational Attainment: A comparative sibling analysis," European Societies 5(1), 33-68.

Solon, Gary (1999) "Intergenerational Mobility in the Labor Market," in O. Ashenfelter and D. Card (eds.) Handbook of Labor Economics 3A, Elsevier, Amsterdam, North Holland.

Solon, G., M. Page, and G. Duncan (2000) "Correlations between Neighboring Children in Their Subsequent Educational Attainment," Review of Economics and Statistics 82(3), 38392.

Solon Gary, Mary Corcoran, Roger Gordon and Deborah Laren (1991) "A Longitudinal Study of Sibling Correlations in Economic Status," Journal of Human Resources 26 (Summer), 50934.

Stenberg Sten-Åke (2000) “An intergenerational study of social assistance recipiency in postwar Sweden,” Journal of Marriage and the Family 62(1), 228-39.

Stenberg Sten-Åke and Denny Vågerö (2006) "Cohort Profile: The Stockholm Birth Cohort of 1953,” International Journal of Epidemiology 35, 546-48. 
Table 1. Descriptive Statistics: Socio-Economic Status, Family Structure and Social Problems.

\begin{tabular}{|c|c|c|c|c|c|c|c|c|c|c|c|}
\hline & & \multicolumn{5}{|c|}{ full sample } & \multicolumn{5}{|c|}{ Family Survey sample } \\
\hline & & $\begin{array}{l}\text { mean } \\
\text { (s.d.) }\end{array}$ & Median & Min & Max & \#obs & $\begin{array}{l}\text { mean } \\
\text { (s.d.) }\end{array}$ & median & $\min$ & $\max$ & \#obs \\
\hline \multirow{2}{*}{ individuals } & men & & & & & 10167 & & & & & 2537 \\
\hline & women & & & & & 9757 & & & & & 2450 \\
\hline \multirow{2}{*}{ families } & men & & & & & 6585 & & & & & 1608 \\
\hline & women & & & & & 6308 & & & & & 1570 \\
\hline \multirow{2}{*}{ singletons } & men & & & & & 845 & & & & & 168 \\
\hline & women & & & & & 810 & & & & & 195 \\
\hline \multirow{2}{*}{$\begin{array}{l}\text { neighbour- } \\
\text { hoods }\end{array}$} & men & & & & & 165 & & & & & 122 \\
\hline & women & & & & & 121 & & & & & 111 \\
\hline \multirow{2}{*}{$\begin{array}{l}\text { log average } \\
\text { income }\end{array}$} & men & $\begin{array}{c}12.37 \\
(0.569)\end{array}$ & 12.40 & 9.28 & 15.23 & 10167 & $\begin{array}{c}12.42 \\
(0.565)\end{array}$ & 12.43 & 9.41 & 15.21 & 2537 \\
\hline & women & $\begin{array}{c}12.06 \\
(0.472)\end{array}$ & 12.11 & 9.24 & 14.44 & 9757 & $\begin{array}{c}12.07 \\
(0.465)\end{array}$ & 12.11 & 9.60 & 14.44 & 2450 \\
\hline \multicolumn{12}{|c|}{ Socio-Economic Status } \\
\hline \multirow{2}{*}{$\begin{array}{l}\text { log father's } \\
\text { income } \\
1963\end{array}$} & men & $\begin{array}{c}10.13 \\
(0.542)\end{array}$ & 10.09 & 6.91 & 13.50 & 8602 & $\begin{array}{c}10.16 \\
(0.545)\end{array}$ & 10.13 & 7.60 & 13.00 & 2160 \\
\hline & women & $\begin{array}{c}10.13 \\
(0.545)\end{array}$ & 10.09 & 6.91 & 12.66 & 8335 & $\begin{array}{c}10.14 \\
(0.548)\end{array}$ & 10.09 & 6.91 & 12.52 & 2133 \\
\hline \multirow{2}{*}{$\begin{array}{l}\text { log mother's } \\
\text { income } \\
1963\end{array}$} & men & $\begin{array}{c}8.67 \\
(0.912)\end{array}$ & 8.85 & 6.91 & 11.65 & 5029 & $\begin{array}{c}8.64 \\
(0.951)\end{array}$ & 8.78 & 6.91 & 11.65 & 1248 \\
\hline & women & $\begin{array}{c}8.71 \\
(0.906)\end{array}$ & 8.85 & 6.91 & 11.65 & 4978 & $\begin{array}{c}8.69 \\
(0.967)\end{array}$ & 8.85 & 6.91 & 11.65 & 1262 \\
\hline \multirow{2}{*}{$\begin{array}{l}\text { father's } \\
\text { education }\end{array}$} & men & $\begin{array}{c}1.35 \\
(0.646)\end{array}$ & 1 & 1 & 3 & 9702 & $\begin{array}{c}1.40 \\
(0.690)\end{array}$ & 1 & 1 & 3 & 2444 \\
\hline & women & $\begin{array}{c}1.35 \\
(0.643)\end{array}$ & 1 & 1 & 3 & 9320 & $\begin{array}{l}1.40 \\
(0.687)\end{array}$ & 1 & 1 & 3 & 2353 \\
\hline \multirow{2}{*}{$\begin{array}{l}\text { mother's } \\
\text { education }\end{array}$} & men & $\begin{array}{c}1.10 \\
(0.358)\end{array}$ & 1 & 1 & 3 & 9702 & $\begin{array}{c}1.12 \\
(0.400)\end{array}$ & 1 & 1 & 3 & 2444 \\
\hline & women & $\begin{array}{c}1.09 \\
(0.347)\end{array}$ & 1 & 1 & 3 & 9320 & $\begin{array}{c}1.11 \\
(0.390)\end{array}$ & 1 & 1 & 3 & 2353 \\
\hline \multirow{2}{*}{$\begin{array}{l}\text { father's } \\
\text { occupational } \\
\text { category ' } 53\end{array}$} & men & $\begin{array}{c}3.09 \\
(1.397)\end{array}$ & 3 & 1 & 5 & 9823 & $\begin{array}{c}3.04 \\
(1.418)\end{array}$ & 3 & 1 & 5 & 2455 \\
\hline & women & $\begin{array}{c}3.10 \\
(1.397)\end{array}$ & 3 & 1 & 5 & 9442 & $\begin{array}{c}3.05 \\
(1.424)\end{array}$ & 3 & 1 & 5 & 2382 \\
\hline \multirow{2}{*}{$\begin{array}{l}\text { father's } \\
\text { occupational } \\
\text { category ' } 63\end{array}$} & men & $\begin{array}{c}2.87 \\
(1.400)\end{array}$ & 2 & 1 & 5 & 9850 & $\begin{array}{c}2.81 \\
(1.411)\end{array}$ & 2 & 1 & 5 & 2472 \\
\hline & women & $\begin{array}{c}2.87 \\
(1.394)\end{array}$ & 2 & 1 & 5 & 9513 & $\begin{array}{c}2.85 \\
(1.421) \\
\end{array}$ & 2 & 1 & 5 & 2413 \\
\hline
\end{tabular}

\section{Family Structure}

$\begin{array}{llcllllcllll}\text { mother's } & \text { men } & \begin{array}{c}24.92 \\ (4.773)\end{array} & 24 & 15 & 46 & 10167 & \begin{array}{c}25.08 \\ (4.805)\end{array} & 25 & 15 & 45 & 2537\end{array}$ $\begin{array}{llclllllllll}\text { age at first } & & 24.85 & 24 & 15 & 47 & 9757 & 24.83 & 24 & 15 & 46 & 2450\end{array}$

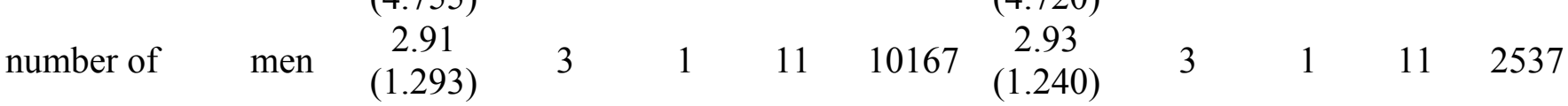




\begin{tabular}{|c|c|c|c|c|c|c|c|c|c|c|c|}
\hline $\begin{array}{l}\text { children in } \\
\text { family }\end{array}$ & women & $\begin{array}{c}2.94 \\
(1.318)\end{array}$ & 3 & 1 & 12 & 9757 & $\begin{array}{c}2.94 \\
(1.300)\end{array}$ & 3 & 1 & 11 & 2450 \\
\hline \multirow{2}{*}{$\begin{array}{l}\text { family type } \\
1960\end{array}$} & men & $\begin{array}{c}2.13 \\
(0.639)\end{array}$ & 2 & 1 & 5 & 9701 & $\begin{array}{c}2.13 \\
(0.631)\end{array}$ & 2 & 1 & 5 & 2444 \\
\hline & women & $\begin{array}{c}2.12 \\
(0.640)\end{array}$ & 2 & 1 & 5 & 9318 & $\begin{array}{c}2.09 \\
(0.548)\end{array}$ & 2 & 1 & 5 & 2353 \\
\hline \multirow{2}{*}{$\begin{array}{l}\text { family type } \\
1963\end{array}$} & men & $\begin{array}{c}1.10 \\
(0.357)\end{array}$ & 1 & 1 & 6 & 10166 & $\begin{array}{c}1.10 \\
(0.370)\end{array}$ & 1 & 1 & 6 & 2537 \\
\hline & women & $\begin{array}{c}1.11 \\
(0.395)\end{array}$ & 1 & 1 & 6 & 9755 & $\begin{array}{c}1.10 \\
(0.371)\end{array}$ & 1 & 1 & 5 & 2450 \\
\hline \multicolumn{12}{|c|}{ Social Problems } \\
\hline \multirow{2}{*}{$\begin{array}{l}\text { social } \\
\text { support }\end{array}$} & men & $\begin{array}{c}0.23 \\
(0.422)\end{array}$ & 0 & 0 & 1 & 10167 & $\begin{array}{c}0.22 \\
(0.415)\end{array}$ & 0 & 0 & 1 & 2537 \\
\hline & women & $\begin{array}{c}0.22 \\
(0.413)\end{array}$ & 0 & 0 & 1 & 9757 & $\begin{array}{c}0.21 \\
(0.407)\end{array}$ & 0 & 0 & 1 & 2450 \\
\hline \multirow{2}{*}{ alcohol } & men & $\begin{array}{c}0.07 \\
(0.252)\end{array}$ & 0 & 0 & 1 & 10167 & $\begin{array}{c}0.07 \\
(0.260)\end{array}$ & 0 & 0 & 1 & 2537 \\
\hline & women & $\begin{array}{c}0.07 \\
(0.253)\end{array}$ & 0 & 0 & 1 & 9757 & $\begin{array}{c}0.07 \\
(0.246)\end{array}$ & 0 & 0 & 1 & 2450 \\
\hline \multirow{2}{*}{$\begin{array}{l}\text { mental } \\
\text { illness }\end{array}$} & men & $\begin{array}{c}0.07 \\
(0.250)\end{array}$ & 0 & 0 & 1 & 10167 & $\begin{array}{c}0.06 \\
(0.231)\end{array}$ & 0 & 0 & 1 & 2537 \\
\hline & women & $\begin{array}{c}0.07 \\
(0.252)\end{array}$ & 0 & 0 & 1 & 9757 & $\begin{array}{c}0.07 \\
(0.247)\end{array}$ & 0 & 0 & 1 & 2450 \\
\hline \multirow{2}{*}{$\begin{array}{l}\text { father's } \\
\text { crime } \\
\text { (extensive) }\end{array}$} & men & $\begin{array}{c}0.13 \\
(0.333)\end{array}$ & 0 & 0 & 1 & 10167 & $\begin{array}{c}0.13 \\
(0.341)\end{array}$ & 0 & 0 & 1 & 2537 \\
\hline & women & $\begin{array}{c}0.13 \\
(0.340)\end{array}$ & 0 & 0 & 1 & 9757 & $\begin{array}{c}0.12 \\
(0.330)\end{array}$ & 0 & 0 & 1 & 2450 \\
\hline \multirow{2}{*}{$\begin{array}{l}\text { father's } \\
\text { crime } \\
\text { (intensive) }\end{array}$} & men & $\begin{array}{c}0.27 \\
(1.043)\end{array}$ & 0 & 0 & 19 & 10167 & $\begin{array}{c}0.30 \\
(1.143)\end{array}$ & 0 & 0 & 17 & 2537 \\
\hline & women & $\begin{array}{c}0.30 \\
(1.170)\end{array}$ & 0 & 0 & 20 & 9757 & $\begin{array}{c}0.26 \\
(0.980)\end{array}$ & 0 & 0 & 15 & 2450 \\
\hline \multirow{2}{*}{$\begin{array}{l}\text { parental } \\
\text { deaths }\end{array}$} & men & $\begin{array}{c}0.02 \\
(0.125)\end{array}$ & 0 & 0 & 1 & 10167 & $\begin{array}{c}0.01 \\
(0.118)\end{array}$ & 0 & 0 & 1 & 2537 \\
\hline & women & $\begin{array}{c}0.01 \\
(0.111)\end{array}$ & 0 & 0 & 1 & 9757 & $\begin{array}{c}0.01 \\
(0.117)\end{array}$ & 0 & 0 & 1 & 2450 \\
\hline
\end{tabular}


Table 2. Questions and Answers Taken from the Family Study.

\section{Parental Involvement in Schoolwork}

\begin{tabular}{|c|c|c|c|c|c|c|}
\hline & $\begin{array}{l}\text { (1) very } \\
\text { often }\end{array}$ & $\begin{array}{l}\text { (2) rather } \\
\text { often }\end{array}$ & $\begin{array}{l}\text { (3) now and } \\
\text { then }\end{array}$ & $\begin{array}{l}\text { (4) rather } \\
\text { seldom }\end{array}$ & $\begin{array}{l}\text { (5) almost } \\
\text { never }\end{array}$ & $\begin{array}{c}\text { (6) do } \\
\text { not } \\
\text { know }\end{array}$ \\
\hline \multicolumn{7}{|c|}{ Do you and your daughter/son ever talk about what she/he has read/done in school? } \\
\hline Sons & 881 & 825 & 649 & 114 & 61 & 3 \\
\hline Daughters & 915 & 793 & 600 & 82 & 57 & 0 \\
\hline \multicolumn{7}{|c|}{$\begin{array}{l}\text { Have you read in your daughter's/son's schoolbooks to see what she/he is learning in school } \\
\text { and to keep up a little yourself? }\end{array}$} \\
\hline Sons & 370 & 532 & 948 & 387 & 293 & 3 \\
\hline Daughters & 363 & 494 & 977 & 347 & 260 & 4 \\
\hline \multicolumn{7}{|c|}{ Do you usually help her/him with her/his homework by questioning, etc.? } \\
\hline Sons & 189 & 307 & 609 & 439 & 987 & 1 \\
\hline Daughters & 179 & 294 & 677 & 430 & 860 & 3 \\
\hline \multicolumn{7}{|c|}{$\begin{array}{l}\text { Do your husband and your daughter/son ever talk about what she/he has read/done in } \\
\text { school? }\end{array}$} \\
\hline Sons & 456 & 526 & 749 & 278 & 232 & 6 \\
\hline Daughters & 444 & 507 & 712 & 275 & 226 & 11 \\
\hline \multicolumn{7}{|c|}{$\begin{array}{l}\text { Does your husband read in your daughter's/son's schoolbooks to see what she/he is learning } \\
\text { in school and to keep up a little himself? }\end{array}$} \\
\hline Sons & 196 & 354 & 716 & 423 & 536 & 22 \\
\hline Daughters & 204 & 360 & 686 & 396 & 510 & 20 \\
\hline \multicolumn{7}{|c|}{ Does your husband usually help her/him with her/his homework by questioning, etc.? } \\
\hline Sons & 118 & 212 & 601 & 334 & 979 & 3 \\
\hline Daughters & 146 & 238 & 588 & 350 & 845 & 4 \\
\hline
\end{tabular}
(0) no
(1) yes,
(2) yes, several
(3) do not once times know

Have you been to a Parent Teacher Association meeting this school year and if so, have you been more than once?

$\begin{array}{lllll}\text { Sons } & 1179 & 949 & 403 & 2 \\ \text { Daughters } & 1124 & 935 & 386 & 3\end{array}$

Has your husband been to a Parent Teacher Association meeting this school year and if so, has he been more than once?

$\begin{array}{lllll}\text { Sons } & 1399 & 664 & 231 & 4 \\ \text { Daughters } & 1563 & 607 & 230 & 2\end{array}$

\section{Parenting firmness}

\begin{tabular}{lcccccc}
\hline & $\begin{array}{c}\text { (1) quite } \\
\text { right }\end{array}$ & $\begin{array}{c}(2) \\
\text { generally, } \\
\text { right }\end{array}$ & $\begin{array}{c}\text { (3) neither right } \\
\text { nor wrong }\end{array}$ & $\begin{array}{c}\text { (4) } \\
\text { generally, } \\
\text { wrong }\end{array}$ & $\begin{array}{c}\text { (5) do do } \\
\text { not } \\
\text { know }\end{array}$ \\
\hline $\begin{array}{l}\text { Children must learn to obey. } \\
\text { Sons }\end{array}$ & 1503 & 786 & 159 & 55 & 31 & 2 \\
Daughters & 1423 & 788 & 151 & 64 & 22 & 2 \\
Children must have firm rules. & 1663 & 726 & 118 & 26 & 2 & 1 \\
Sons & 1584 & 713 & 117 & 28 & 3 & 5 \\
Daughters & 1584 & & & & &
\end{tabular}


Children must respect their parents.

\begin{tabular}{|c|c|c|c|c|c|c|}
\hline Sons & 812 & 817 & 453 & 241 & 197 & 16 \\
\hline Daughters & 740 & 767 & 496 & 241 & 193 & 13 \\
\hline \multicolumn{7}{|c|}{ Children should be taught to control themselves. } \\
\hline Sons & 615 & 1077 & 544 & 218 & 77 & 5 \\
\hline Daughters & 594 & 1056 & 509 & 225 & 64 & 2 \\
\hline \multicolumn{7}{|c|}{ You have to be consistent when raising children. } \\
\hline Sons & 1717 & 713 & 73 & 13 & 7 & \\
\hline Daughters & 1646 & 690 & 80 & 19 & 4 & \\
\hline
\end{tabular}

Parental Patience

\begin{tabular}{|c|c|c|c|c|c|c|}
\hline & $\begin{array}{l}\text { (1) yes, } \\
\text { definitely }\end{array}$ & $\begin{array}{l}\text { (2) yes, } \\
\text { perhaps }\end{array}$ & (3) do not know & $\begin{array}{l}\text { (4) no, } \\
\text { perhaps } \\
\text { not }\end{array}$ & defir & $\begin{array}{l}\text { (5) no, } \\
\text { nitely not }\end{array}$ \\
\hline \multicolumn{7}{|c|}{$\begin{array}{l}\text { If you could choose between 1,000 SEK now and 10,000 SEK in five years, would you choose } \\
\text { 1,000 SEK now? }\end{array}$} \\
\hline \multicolumn{7}{|c|}{$\begin{array}{lrllll}1,000 & \text { SEK now? } \\
\text { Sons } & 401 & 242 & 141 & 208 & 1544\end{array}$} \\
\hline Daughters & 410 & 230 & 157 & 205 & & 1447 \\
\hline \multicolumn{7}{|c|}{ Do you think one gets more out of life if one thinks matters over carefully first? } \\
\hline Sons & 614 & 757 & 191 & 539 & & 433 \\
\hline Daughters & 602 & 696 & 162 & 559 & & 431 \\
\hline \multicolumn{7}{|c|}{ Do you like to make long-term plans? } \\
\hline Sons & 749 & 816 & 62 & 431 & & 478 \\
\hline Daughters & 712 & 773 & 68 & 424 & & 473 \\
\hline \multicolumn{7}{|c|}{ Do you think it is worth planning for the future? } \\
\hline Sons & 1061 & 793 & 220 & 247 & & 215 \\
\hline Daughters & 1025 & 789 & 188 & 251 & & 197 \\
\hline \multicolumn{7}{|c|}{ Do you often think about the future? } \\
\hline Sons & 716 & 752 & 40 & 575 & & 451 \\
\hline Daughters & 721 & 661 & 49 & 577 & & 441 \\
\hline \multicolumn{7}{|c|}{ Do you think your future mainly depends on chance? } \\
\hline Sons & 417 & 732 & 288 & 465 & & 633 \\
\hline Daughters & 398 & 667 & 313 & 460 & & 608 \\
\hline \multicolumn{7}{|c|}{ Do you like doing things you have not planned ahead of time? } \\
\hline Sons & 1009 & 820 & 94 & 347 & & 266 \\
\hline Daughters & 1000 & 827 & 93 & 304 & & 226 \\
\hline \multicolumn{7}{|c|}{ Do you like saving up money for something big? } \\
\hline Sons & 1390 & 671 & 111 & 178 & & 184 \\
\hline Daughters & 1282 & 697 & 99 & 197 & & 173 \\
\hline \multicolumn{7}{|c|}{ Do you think that you yourself can influence your future through your present actions? } \\
\hline Sons & 915 & 928 & 307 & 208 & & 175 \\
\hline Daughters & 920 & 916 & 278 & 196 & & 137 \\
\hline \multicolumn{7}{|c|}{ Number of Books in the Household } \\
\hline & none $\approx 1$ & $\begin{array}{c}26- \\
10\end{array}$ & $\approx$ & $\begin{array}{cc}\approx & \approx \\
300 & 1000\end{array}$ & $\begin{array}{c}>= \\
3000\end{array}$ & do not know \\
\hline \multicolumn{7}{|c|}{ How many books do you think there are in this apartment/house? } \\
\hline Sons & 65 & 26219 & 793903 & $474 \quad 101$ & 9 & 1 \\
\hline Daughters & 4 & $31 \quad 222$ & 787 & 448 & 2 & 0 \\
\hline
\end{tabular}


Table 3A. The Importance of Parental Income and Education, Father's Socio-Economic Status and Neighborhood Effects for Sibling Correlations in Income. Family Survey Sample.

\begin{tabular}{|c|c|c|c|c|c|c|c|c|c|}
\hline & & Men & & & Women & & & Pooled & \\
\hline & & & & Bas & line Esti & zates & & & \\
\hline Sibling Correlation & & 0.221 & & & 0.248 & & & 0.215 & \\
\hline (s.e.) & & $(0.042)$ & & & $(0.040)$ & & & $(0.022)$ & \\
\hline Family Component & & 0.070 & & & 0.053 & & & 0.058 & \\
\hline (s.e.) & & $(0.014)$ & & & (0.009) & & & $(0.006)$ & \\
\hline & & $\downarrow$ & $\% \downarrow$ & & - & $\% \downarrow$ & & $\downarrow$ & $\% \downarrow$ \\
\hline & & & & Fixed $N \epsilon$ & ighborho & $d$ Effe & & & \\
\hline $\begin{array}{l}\text { Sibling Correlation } \\
\text { (s.e.) }\end{array}$ & $\begin{array}{c}0.217 \\
(0.042)\end{array}$ & 0.004 & 1.6 & $\begin{array}{l}0.215 \\
(0.043)\end{array}$ & 0.034 & 13.5 & $\begin{array}{l}0.201 \\
(0.023)\end{array}$ & 0.014 & 6.6 \\
\hline $\begin{array}{l}\text { Family Component } \\
\text { (s.e.) }\end{array}$ & $\begin{array}{l}0.068 \\
(0.014)\end{array}$ & 0.003 & 3.8 & $\begin{array}{l}0.046 \\
(0.010)\end{array}$ & 0.008 & 14.7 & $\begin{array}{l}0.053 \\
(0.006)\end{array}$ & 0.005 & 8.0 \\
\hline & & & & & her's Inc & me & & & \\
\hline $\begin{array}{l}\text { Sibling Correlation } \\
\text { (s.e.) }\end{array}$ & $\begin{array}{l}0.175 \\
(0.043)\end{array}$ & 0.046 & 20.1 & $\begin{array}{l}0.235 \\
(0.040)\end{array}$ & 0.014 & 5.6 & $\begin{array}{l}0.189 \\
(0.022)\end{array}$ & 0.026 & 11.9 \\
\hline $\begin{array}{l}\text { Family Component } \\
\text { (s.e.) }\end{array}$ & $\begin{array}{l}0.053 \\
(0.013)\end{array}$ & 0.017 & 24.5 & $\begin{array}{l}0.050 \\
(0.009)\end{array}$ & 0.004 & 7.0 & $\begin{array}{l}0.049 \\
(0.006)\end{array}$ & 0.008 & 14.7 \\
\hline & & & & Mo & her's Inc & ome & & & \\
\hline $\begin{array}{l}\text { Sibling Correlation } \\
\text { (s.e.) }\end{array}$ & $\begin{array}{l}0.218 \\
(0.042)\end{array}$ & 0.003 & 1.4 & $\begin{array}{l}0.246 \\
(0.040)\end{array}$ & 0.002 & 1.0 & $\begin{array}{l}0.214 \\
(0.022)\end{array}$ & 0.001 & 0.7 \\
\hline $\begin{array}{l}\text { Family Component } \\
\text { (s.e.) }\end{array}$ & $\begin{array}{l}0.069 \\
(0.014)\end{array}$ & 0.001 & 2.0 & $\begin{array}{l}0.053 \\
(0.009)\end{array}$ & 0.001 & 1.2 & $\begin{array}{l}0.057 \\
(0.006)\end{array}$ & 0.001 & 1.0 \\
\hline & & & & Fath & er's Educ & ation & & & \\
\hline $\begin{array}{l}\text { Sibling Correlation } \\
\text { (s.e.) }\end{array}$ & $\begin{array}{l}0.157 \\
(0.043)\end{array}$ & 0.064 & 29.0 & $\begin{array}{l}0.228 \\
(0.040)\end{array}$ & 0.020 & 8.0 & $\begin{array}{l}0.179 \\
(0.022)\end{array}$ & 0.037 & 17.0 \\
\hline $\begin{array}{l}\text { Family Component } \\
\text { (s.e.) }\end{array}$ & $\begin{array}{l}0.046 \\
(0.013)\end{array}$ & 0.024 & 33.8 & $\begin{array}{l}0.048 \\
(0.009)\end{array}$ & 0.005 & 10.1 & $\begin{array}{l}0.046 \\
(0.006)\end{array}$ & 0.012 & 20.7 \\
\hline $\begin{array}{l}\text { Sibling Correlation } \\
\text { (s.e.) }\end{array}$ & $\begin{array}{l}0.197 \\
(0.042)\end{array}$ & 0.024 & 10.9 & $\begin{array}{l}\quad \text { Mot } \\
0.232 \\
(0.040)\end{array}$ & $\begin{array}{c}\text { er's Edu } \\
0.016\end{array}$ & $\begin{array}{l}\text { ation } \\
7.0\end{array}$ & $\begin{array}{l}0.196 \\
(0.022)\end{array}$ & 0.019 & 8.7 \\
\hline $\begin{array}{l}\text { Family Component } \\
\text { (s.e.) }\end{array}$ & $\begin{array}{l}0.061 \\
(0.013)\end{array}$ & 0.009 & 13.5 & $\begin{array}{l}0.049 \\
(0.009)\end{array}$ & 0.004 & 8.1 & $\begin{array}{l}0.051 \\
(0.006)\end{array}$ & 0.006 & 10.9 \\
\hline & & & & ather's $S$ & cio-Ecor & omic $S$ & & & \\
\hline $\begin{array}{l}\text { Sibling Correlation } \\
\text { (s.e.) }\end{array}$ & $\begin{array}{l}0.149 \\
(0.043)\end{array}$ & 0.072 & 32.6 & $\begin{array}{l}0.222 \\
(0.040)\end{array}$ & 0.026 & 10.5 & $\begin{array}{l}0.163 \\
(0.023)\end{array}$ & 0.052 & 24.3 \\
\hline $\begin{array}{l}\text { Family Component } \\
\text { (s.e.) }\end{array}$ & $\begin{array}{l}0.044 \\
(0.013)\end{array}$ & 0.027 & 37.8 & $\begin{array}{l}0.046 \\
(0.009)\end{array}$ & 0.007 & 13.9 & $\begin{array}{l}0.041 \\
(0.006)\end{array}$ & 0.017 & 28.7 \\
\hline & & & & & ll Contro & & & & \\
\hline $\begin{array}{l}\text { Sibling Correlation } \\
\text { (s.e.) }\end{array}$ & $\begin{array}{l}0.139 \\
(0.045)\end{array}$ & 0.081 & 36.9 & $\begin{array}{l}0.190 \\
(0.044)\end{array}$ & 0.059 & 23.7 & $\begin{array}{l}0.149 \\
(0.023)\end{array}$ & 0.066 & 30.7 \\
\hline $\begin{array}{l}\text { Family Component } \\
\text { (s.e.) }\end{array}$ & $\begin{array}{l}0.040 \\
(0.013) \\
\end{array}$ & 0.030 & 43.0 & $\begin{array}{l}0.039 \\
(0.009) \\
\end{array}$ & 0.014 & 27.7 & $\begin{array}{l}0.037 \\
(0.006)\end{array}$ & 0.020 & 35.6 \\
\hline
\end{tabular}

$\downarrow$ gives the absolute decrease, $\% \downarrow$ gives the percentage decrease. Percentage decreases $>10 \%$ are shaded. 
Table 3B. The Importance of Parental Income and Education, Father's Socio-Economic Status and Neighborhood Effects for Sibling Correlations in Income. Full Sample.

\begin{tabular}{|c|c|c|c|c|c|c|c|c|c|}
\hline & & Men & & & Women & & & Pooled & \\
\hline & & & & Bas & line Esti & zates & & & \\
\hline Sibling Correlation & & 0.267 & & & 0.168 & & & 0.190 & \\
\hline (s.e.) & & $(0.022)$ & & & $(0.021)$ & & & $(0.012)$ & \\
\hline Family Component & & 0.086 & & & 0.037 & & & 0.052 & \\
\hline (s.e.) & & $(0.007)$ & & & $(0.005)$ & & & $(0.003)$ & \\
\hline & & $\downarrow$ & $\% \downarrow$ & & 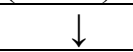 & $\% \downarrow$ & & $\downarrow$ & $\% \downarrow$ \\
\hline & & & & Fixed $N \epsilon$ & ighborho & $d$ Effe & & & \\
\hline $\begin{array}{l}\text { Sibling Correlation } \\
\text { (s.e.) }\end{array}$ & $\begin{array}{c}0.252 \\
(0.022)\end{array}$ & 0.015 & 5.6 & $\begin{array}{l}0.154 \\
(0.022)\end{array}$ & 0.014 & 8.4 & $\begin{array}{l}0.179 \\
(0.012)\end{array}$ & 0.011 & 6.0 \\
\hline $\begin{array}{l}\text { Family Component } \\
\text { (s.e.) }\end{array}$ & $\begin{array}{l}0.080 \\
(0.007)\end{array}$ & 0.006 & 7.5 & $\begin{array}{l}0.034 \\
(0.005)\end{array}$ & 0.003 & 9.0 & $\begin{array}{l}0.048 \\
(0.003)\end{array}$ & 0.004 & 7.1 \\
\hline & & & & & her's Inc & me & & & \\
\hline $\begin{array}{l}\text { Sibling Correlation } \\
\text { (s.e.) }\end{array}$ & $\begin{array}{l}0.234 \\
(0.022)\end{array}$ & 0.033 & 12.5 & $\begin{array}{l}0.157 \\
(0.021)\end{array}$ & 0.011 & 6.4 & $\begin{array}{l}0.168 \\
(0.012)\end{array}$ & 0.022 & 11.5 \\
\hline $\begin{array}{l}\text { Family Component } \\
\text { (s.e.) }\end{array}$ & $\begin{array}{l}0.073 \\
(0.007)\end{array}$ & 0.013 & 15.4 & $\begin{array}{l}0.035 \\
(0.005)\end{array}$ & 0.003 & 7.5 & $\begin{array}{l}0.045 \\
(0.003)\end{array}$ & 0.007 & 13.5 \\
\hline & & & & Mo & ther's Inc & ome & & & \\
\hline $\begin{array}{l}\text { Sibling Correlation } \\
\text { (s.e.) }\end{array}$ & $\begin{array}{l}0.266 \\
(0.022)\end{array}$ & 0.013 & 0.5 & $\begin{array}{l}0.168 \\
(0.021)\end{array}$ & 0.001 & 0.4 & $\begin{array}{l}0.190 \\
(0.012)\end{array}$ & 0.000 & 0.2 \\
\hline $\begin{array}{l}\text { Family Component } \\
\text { (s.e.) }\end{array}$ & $\begin{array}{l}0.086 \\
(0.007)\end{array}$ & 0.001 & 0.6 & $\begin{array}{l}0.037 \\
(0.005)\end{array}$ & 0.000 & 0.4 & $\begin{array}{l}0.052 \\
(0.003)\end{array}$ & 0.000 & 0.3 \\
\hline & & & & Fath & er's Educ & ation & & & \\
\hline $\begin{array}{l}\text { Sibling Correlation } \\
\text { (s.e.) }\end{array}$ & $\begin{array}{l}0.228 \\
(0.022)\end{array}$ & 0.039 & 14.4 & $\begin{array}{l}0.156 \\
(0.021)\end{array}$ & 0.012 & 7.2 & $\begin{array}{l}0.164 \\
(0.012)\end{array}$ & 0.026 & 13.6 \\
\hline $\begin{array}{l}\text { Family Component } \\
\text { (s.e.) }\end{array}$ & $\begin{array}{l}0.071 \\
(0.007)\end{array}$ & 0.015 & 17.5 & $\begin{array}{l}0.034 \\
(0.005)\end{array}$ & 0.003 & 8.7 & $\begin{array}{l}0.044 \\
(0.003)\end{array}$ & 0.008 & 15.8 \\
\hline $\begin{array}{l}\text { Sibling Correlation } \\
\text { (s.e.) }\end{array}$ & $\begin{array}{l}0.252 \\
(0.022)\end{array}$ & 0.015 & 5.8 & $\begin{array}{l}\quad \text { Mot } \\
0.163 \\
(0.021)\end{array}$ & $\begin{array}{l}\text { er's } E d u \\
0.005\end{array}$ & $\begin{array}{l}\text { ation } \\
3.1\end{array}$ & $\begin{array}{l}0.181 \\
(0.012)\end{array}$ & 0.010 & 5.1 \\
\hline $\begin{array}{l}\text { Family Component } \\
\text { (s.e.) }\end{array}$ & $\begin{array}{l}0.080 \\
(0.007)\end{array}$ & 0.006 & 7.1 & $\begin{array}{l}0.036 \\
(0.005)\end{array}$ & 0.001 & 3.8 & $\begin{array}{l}0.049 \\
(0.003)\end{array}$ & 0.003 & 6.1 \\
\hline & & & & ather's $S$ & cio-Ecor & omic $S$ & & & \\
\hline $\begin{array}{l}\text { Sibling Correlation } \\
\text { (s.e.) }\end{array}$ & $\begin{array}{l}0.222 \\
(0.022)\end{array}$ & 0.047 & 17.6 & $\begin{array}{l}0.156 \\
(0.021)\end{array}$ & 0.013 & 7.5 & $\begin{array}{l}0.156 \\
(0.012)\end{array}$ & 0.034 & 18.0 \\
\hline $\begin{array}{l}\text { Family Component } \\
\text { (s.e.) }\end{array}$ & $\begin{array}{l}0.068 \\
(0.007)\end{array}$ & 0.019 & 21.6 & $\begin{array}{l}0.034 \\
(0.005)\end{array}$ & 0.003 & 9.2 & $\begin{array}{l}0.041 \\
(0.003)\end{array}$ & 0.011 & 20.7 \\
\hline & & & & & Il Contro & & & & \\
\hline $\begin{array}{l}\text { Sibling Correlation } \\
\text { (s.e.) }\end{array}$ & $\begin{array}{l}0.210 \\
(0.023)\end{array}$ & 0.057 & 21.3 & $\begin{array}{l}0.141 \\
(0.022)\end{array}$ & 0.027 & 16.2 & $\begin{array}{l}0.148 \\
(0.012)\end{array}$ & 0.042 & 22.2 \\
\hline $\begin{array}{l}\text { Family Component } \\
\text { (s.e.) }\end{array}$ & $\begin{array}{l}0.063 \\
(0.007) \\
\end{array}$ & 0.023 & 26.1 & $\begin{array}{l}0.030 \\
(0.005) \\
\end{array}$ & 0.007 & 18.5 & $\begin{array}{l}0.039 \\
(0.003)\end{array}$ & 0.013 & 25.5 \\
\hline
\end{tabular}

\footnotetext{
$\downarrow$ gives the absolute decrease, $\% \downarrow$ gives the percentage decrease. Percentage decreases $>10 \%$ are shaded.
} 
Table 4A. The Importance of Family Structure for Sibling Correlations in Income. Family Survey Sample.

\begin{tabular}{|c|c|c|c|c|c|c|c|c|c|}
\hline & & Men & & & Women & & & Pooled & \\
\hline & & & & Bas & ine Estin & ates & & & \\
\hline Sibling Correlation & & 0.221 & & & 0.248 & & & 0.215 & \\
\hline (s.e.) & & $(0.042)$ & & & $(0.040)$ & & & $(0.022)$ & \\
\hline Family Component & & 0.070 & & & 0.053 & & & 0.058 & \\
\hline (s.e.) & & $(0.014)$ & & & $(0.009)$ & & & $(0.006)$ & \\
\hline & & $\downarrow$ & $\% \downarrow$ & & $\downarrow$ & $\% \downarrow$ & & $\downarrow$ & $\% \downarrow$ \\
\hline & & & & Mother & Age at $F$ & rst Birth & & & \\
\hline $\begin{array}{l}\text { Sibling Correlation } \\
\text { (s.e.) }\end{array}$ & $\begin{array}{l}0.191 \\
(0.043)\end{array}$ & 0.030 & 13.5 & $\begin{array}{l}0.235 \\
(0.040)\end{array}$ & 0.013 & 5.2 & $\begin{array}{l}0.194 \\
(0.023)\end{array}$ & 0.021 & 9.8 \\
\hline $\begin{array}{l}\text { Family Component } \\
\text { (s.e.) }\end{array}$ & $\begin{array}{l}0.059 \\
(0.013)\end{array}$ & 0.011 & 16.1 & $\begin{array}{l}0.050 \\
(0.009)\end{array}$ & 0.003 & 6.5 & $\begin{array}{l}0.051 \\
(0.006)\end{array}$ & 0.007 & 11.8 \\
\hline & & & & Far & ily Type & 960 & & & \\
\hline $\begin{array}{l}\text { Sibling Correlation } \\
\text { (s.e.) }\end{array}$ & $\begin{array}{l}0.209 \\
(0.042)\end{array}$ & 0.012 & 5.4 & $\begin{array}{l}0.246 \\
(0.039)\end{array}$ & 0.003 & 1.1 & $\begin{array}{l}0.210 \\
(0.022)\end{array}$ & 0.006 & 2.6 \\
\hline $\begin{array}{l}\text { Family Component } \\
\text { (s.e.) }\end{array}$ & $\begin{array}{l}0.066 \\
(0.014)\end{array}$ & 0.004 & 6.1 & $\begin{array}{l}0.052 \\
(0.009)\end{array}$ & 0.001 & 1.7 & $\begin{array}{l}0.056 \\
(0.006)\end{array}$ & 0.002 & 3.3 \\
\hline & & & & $\mathrm{Far}$ & ily Tyре & 963 & & & \\
\hline $\begin{array}{l}\text { Sibling Correlation } \\
\text { (s.e.) }\end{array}$ & $\begin{array}{l}0.209 \\
(0.042)\end{array}$ & 0.012 & 5.3 & $\begin{array}{l}0.249 \\
(0.039)\end{array}$ & -0.0002 & -0.1 & $\begin{array}{l}0.210 \\
(0.022)\end{array}$ & 0.005 & 2.5 \\
\hline $\begin{array}{l}\text { Family Component } \\
\text { (s.e.) }\end{array}$ & $\begin{array}{l}0.066 \\
(0.014)\end{array}$ & 0.004 & 6.0 & $\begin{array}{l}0.053 \\
(0.009)\end{array}$ & 0 & 0 & $\begin{array}{l}0.056 \\
(0.006)\end{array}$ & 0.002 & 3.0 \\
\hline & & & & Nun & er of Sib & ings & & & \\
\hline $\begin{array}{l}\text { Sibling Correlation } \\
\text { (s.e.) }\end{array}$ & $\begin{array}{l}0.209 \\
(0.042)\end{array}$ & 0.012 & 5.4 & $\begin{array}{l}0.237 \\
(0.040)\end{array}$ & 0.011 & 4.5 & $\begin{array}{l}0.202 \\
(0.023)\end{array}$ & 0.014 & 6.3 \\
\hline $\begin{array}{l}\text { Family Component } \\
\text { (s.e.) }\end{array}$ & $\begin{array}{l}0.066 \\
(0.014)\end{array}$ & 0.005 & 6.3 & $\begin{array}{l}0.050 \\
(0.009)\end{array}$ & 0.003 & 5.5 & $\begin{array}{l}0.053 \\
(0.006)\end{array}$ & 0.004 & 7.3 \\
\hline & & & & All Famil & Structur & Controls & & & \\
\hline $\begin{array}{l}\text { Sibling Correlation } \\
\text { (s.e.) }\end{array}$ & $\begin{array}{l}0.172 \\
(0.044)\end{array}$ & 0.049 & 22.1 & $\begin{array}{l}0.230 \\
(0.040)\end{array}$ & 0.019 & 7.3 & $\begin{array}{l}0.183 \\
(0.023)\end{array}$ & 0.033 & 15.1 \\
\hline $\begin{array}{l}\text { Family Component } \\
\text { (s.e.) }\end{array}$ & $\begin{array}{l}0.052 \\
(0.014)\end{array}$ & 0.018 & 25.3 & $\begin{array}{l}0.048 \\
(0.009)\end{array}$ & 0.005 & 9.4 & $\begin{array}{l}0.047 \\
(0.006)\end{array}$ & 0.010 & 17.9 \\
\hline & & & & Controls & Ssed in $T$ & bles 3 an & & & \\
\hline $\begin{array}{l}\text { Sibling Correlation } \\
\text { (s.e.) }\end{array}$ & $\begin{array}{l}0.131 \\
(0.045)\end{array}$ & 0.089 & 40.4 & $\begin{array}{l}0.186 \\
(0.044)\end{array}$ & 0.063 & 25.2 & $\begin{array}{l}0.141 \\
(0.024)\end{array}$ & 0.074 & 34.5 \\
\hline $\begin{array}{l}\text { Family Component } \\
\text { (s.e.) }\end{array}$ & $\begin{array}{l}0.037 \\
(0.013)\end{array}$ & 0.033 & 46.7 & $\begin{array}{l}0.038 \\
(0.009)\end{array}$ & 0.016 & 29.5 & $\begin{array}{l}0.035 \\
(0.006)\end{array}$ & 0.023 & 39.6 \\
\hline
\end{tabular}

$\downarrow$ gives the absolute decrease, $\% \downarrow$ gives the percentage decrease. Percentage decreases $>10 \%$ are shaded. 
Table 4B. The Importance of Family Structure for Sibling Correlations in Income. Full sample.

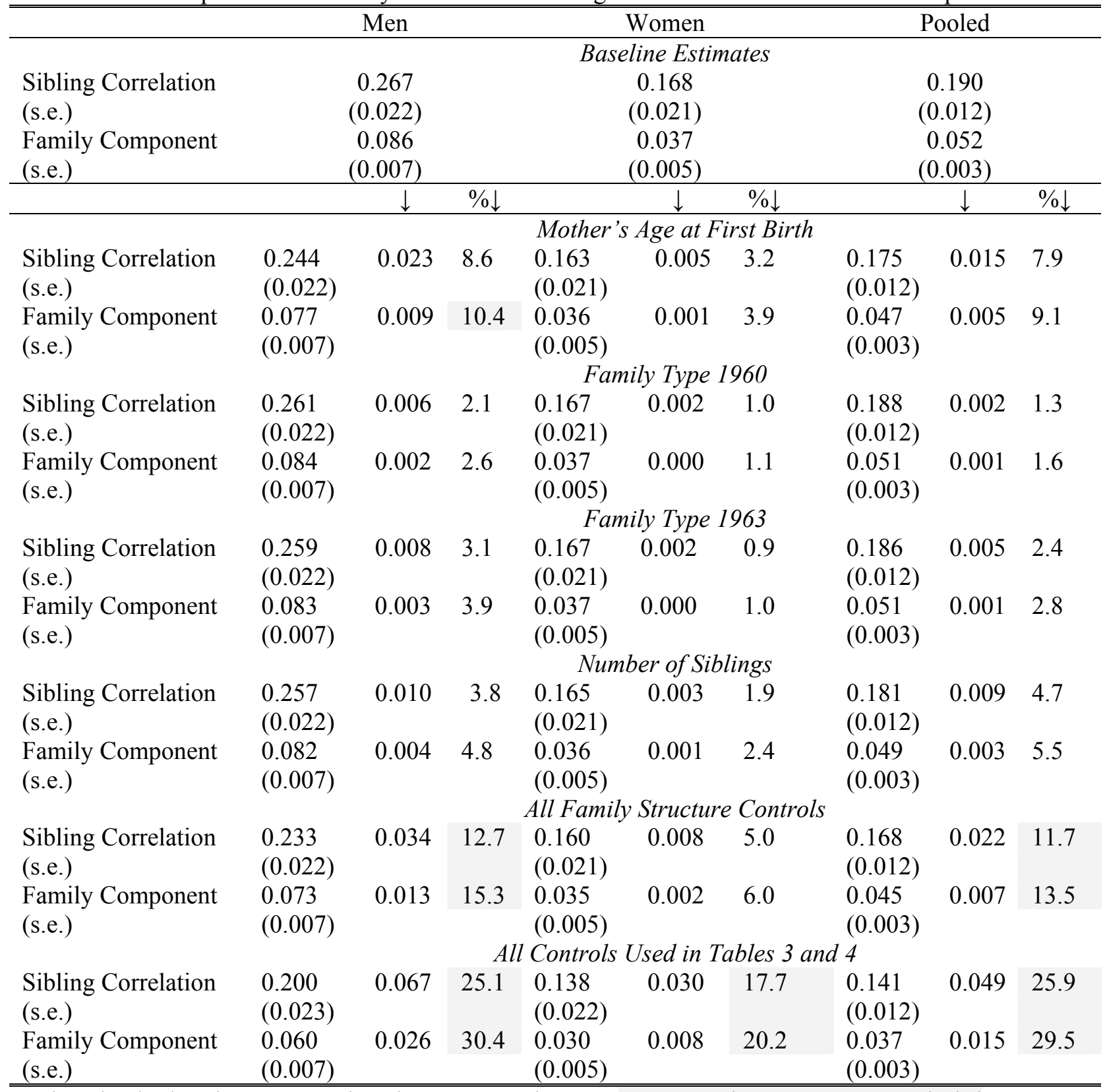

$\downarrow$ gives the absolute decrease, $\% \downarrow$ gives the percentage decrease. Percentage decreases $>10 \%$ are shaded. 
Table 5A. The Importance of Social Problems for Sibling Correlations in Income. Family Survey Sample.

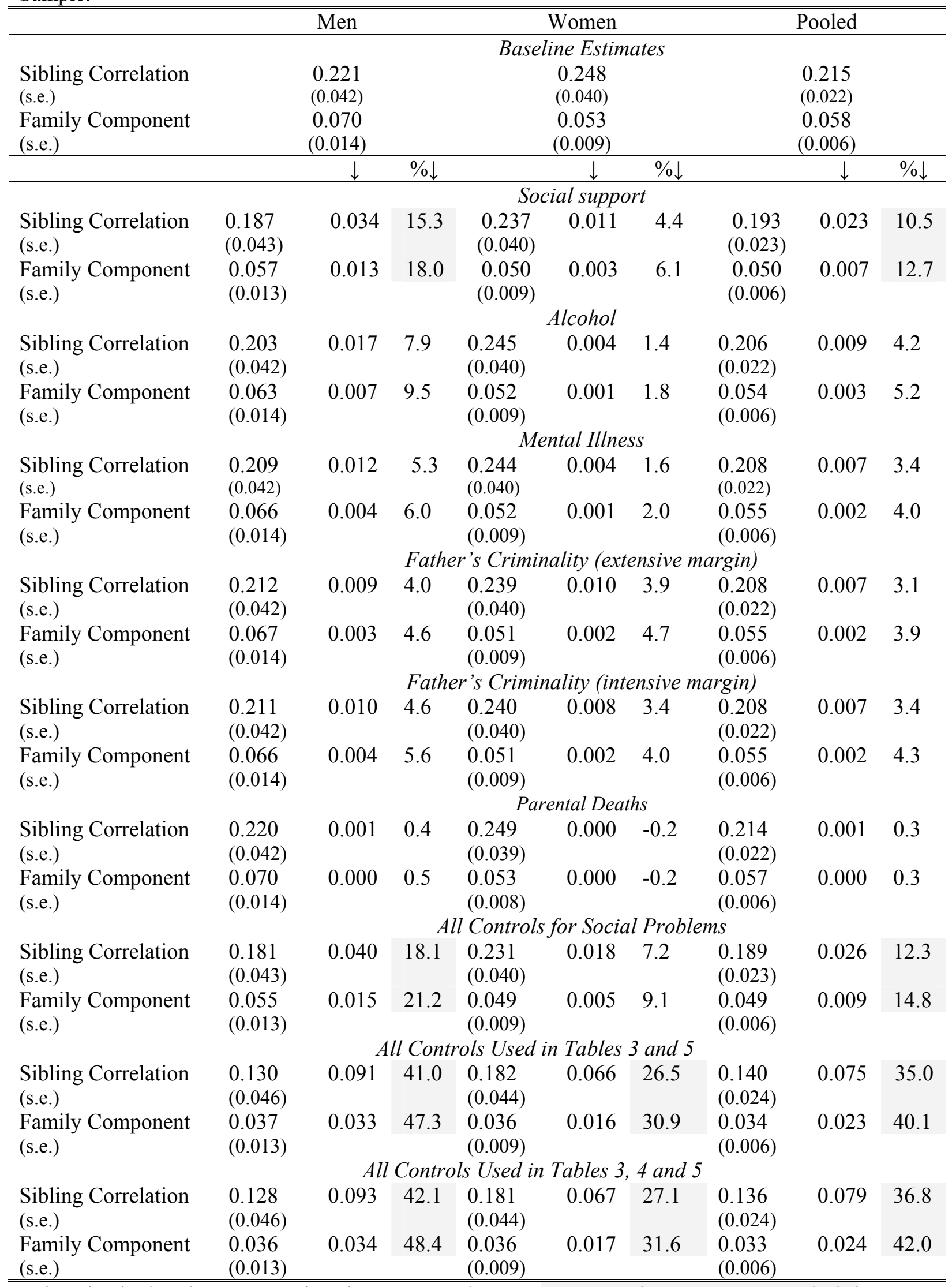

$\downarrow$ gives the absolute decrease, $\% \downarrow$ gives the percentage decrease. Percentage decreases $>10 \%$ are shaded. 
Table 5B. The Importance of Social Problems for Sibling Correlations in Income. Full Sample.

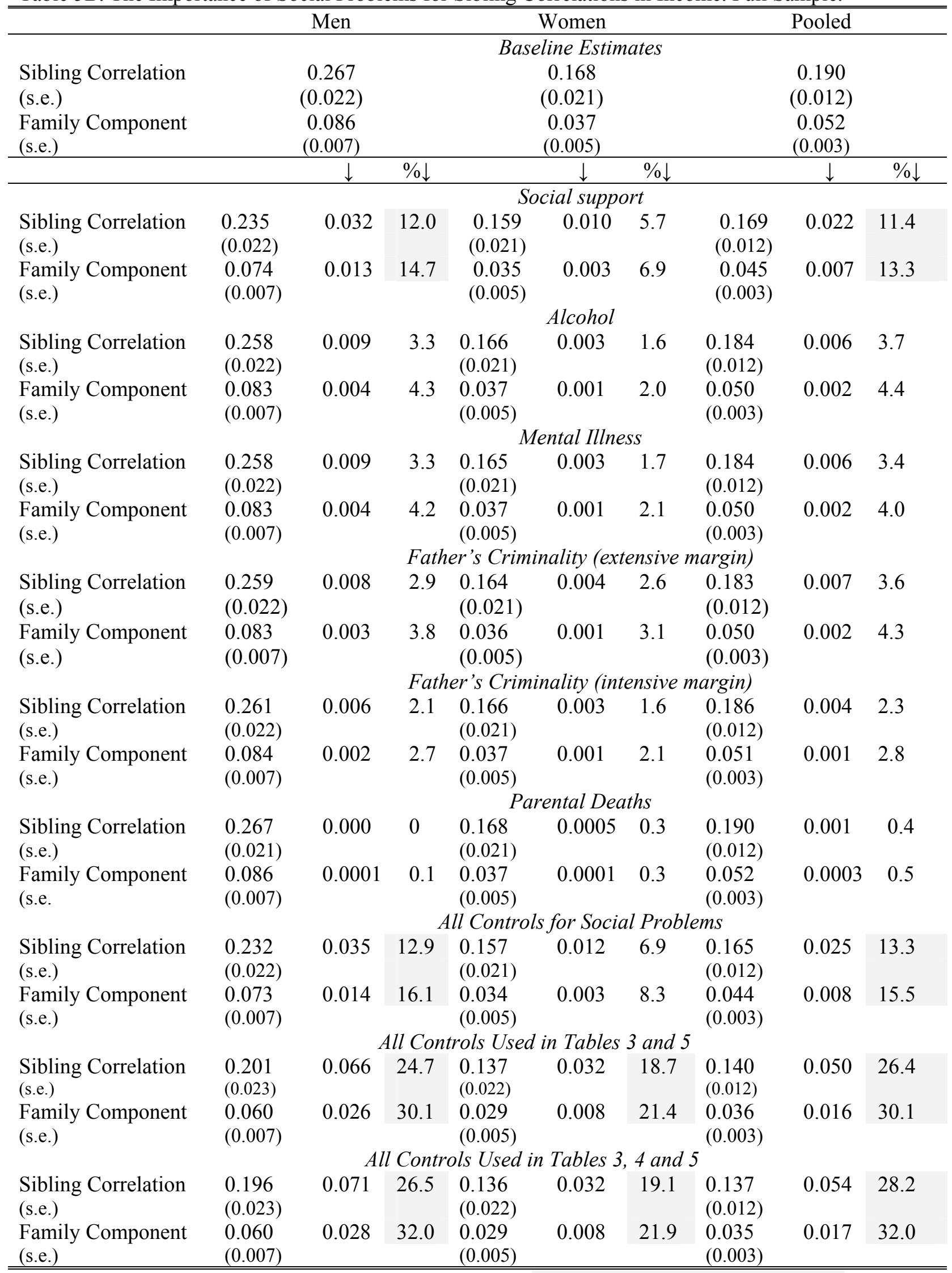

$\downarrow$ gives the absolute decrease, $\% \downarrow$ gives the percentage decrease. Percentage decreases $>10 \%$ are shaded. 
Table 6. The Importance of Parental Involvement and Attitudes for Sibling Correlations in Income. Family Survey Sample.

\begin{tabular}{|c|c|c|c|c|c|c|c|c|c|}
\hline \multirow{3}{*}{$\begin{array}{l}\text { Sibling Correlation } \\
\text { (s.e.) } \\
\text { Family Component } \\
\text { (s.e.) }\end{array}$} & \multicolumn{3}{|c|}{ Men } & \multicolumn{3}{|c|}{ Women } & \multicolumn{3}{|c|}{ Pooled } \\
\hline & \multicolumn{3}{|c|}{$\begin{array}{c}0.221 \\
(0.042) \\
0.070 \\
(0.014)\end{array}$} & Base & $\begin{array}{c}\text { ine Estin } \\
0.248 \\
(0.040) \\
0.053 \\
(0.009) \\
\end{array}$ & ates & & $\begin{array}{c}0.215 \\
(0.022) \\
0.058 \\
(0.006) \\
\end{array}$ & \\
\hline & & $\downarrow$ & $\% \downarrow$ & & $\downarrow$ & $\% \downarrow$ & & $\downarrow$ & $\% \downarrow$ \\
\hline $\begin{array}{l}\text { Sibling Correlation } \\
\text { (s.e.) } \\
\text { Family Component } \\
\text { (s.e.), } t \text {-statistic }\end{array}$ & $\begin{array}{l}0.199 \\
(0.043) \\
0.062 \\
0.014\end{array}$ & 0.008 & 11.8 & $\begin{array}{c}\text { Involvem } \\
0.232 \\
(0.040) \\
0.049 \\
(0.009) \\
\text { Parenting }\end{array}$ & $\begin{array}{r}0.005 \\
\text { Firmnes }\end{array}$ & $\begin{array}{l}\text { olwor } \\
6.6\end{array}$ & $\begin{array}{l}0.196 \\
(0.022) \\
0.051 \\
(0.006)\end{array}$ & 0.007 & 11.3 \\
\hline $\begin{array}{l}\text { Sibling Correlation } \\
\text { (s.e.) } \\
\text { Family Component } \\
\text { (s.e.), } t \text {-statistic }\end{array}$ & $\begin{array}{l}0.208 \\
(0.042) \\
0.064 \\
(0.013)\end{array}$ & $\begin{array}{l}0.013 \\
0.006\end{array}$ & $\begin{array}{l}6.0 \\
8.6\end{array}$ & $\begin{array}{l}0.238 \\
(0.040) \\
0.051 \\
(0.009) \\
\text { Patience }\end{array}$ & 0.010 & 4.1 & $\begin{array}{l}0.199 \\
(0.022) \\
0.052 \\
(0.006)\end{array}$ & 0.016 & 7.3 \\
\hline $\begin{array}{l}\text { Sibling Correlation } \\
\text { (s.e.) } \\
\text { Family Component } \\
\text { (s.e.), } t \text {-statistic }\end{array}$ & $\begin{array}{l}0.184 \\
(0.043) \\
0.056 \\
(0.014)\end{array}$ & $\begin{array}{l}0.037 \\
0.014\end{array}$ & $\begin{array}{l}16.7 \\
19.9\end{array}$ & $\begin{array}{c}0.207 \\
(0.041) \\
0.043 \\
(0.009) \\
\text { Number o }\end{array}$ & $\begin{array}{r}0.041 \\
0.010 \\
\text { fbooks a }\end{array}$ & $\begin{array}{r}16.5 \\
19.5 \\
\text { home }\end{array}$ & $\begin{array}{l}0.181 \\
(0.023) \\
0.047 \\
(0.006)\end{array}$ & 0.034 & 16.0 \\
\hline $\begin{array}{l}\text { Sibling Correlation } \\
\text { (s.e.) } \\
\text { Family Component } \\
\text { (s.e.), } t \text {-statistic }\end{array}$ & $\begin{array}{l}0.182 \\
(0.042) \\
0.055 \\
(0.013)\end{array}$ & $\begin{array}{l}0.039 \\
0.015\end{array}$ & $\begin{array}{c}17.5 \\
21.4 \\
\text { All Co}\end{array}$ & $\begin{array}{l}0.227 \\
(0.040) \\
0.047 \\
(0.009) \\
\text { ntrols for } 1\end{array}$ & $\begin{array}{r}0.021 \\
0.006 \\
\text { nvolvem }\end{array}$ & $\begin{array}{l}8.6 \\
11.2 \\
\text { tt and }\end{array}$ & $\begin{array}{l}0.183 \\
(0.023) \\
0.047 \\
(0.006) \\
\text { titudes }\end{array}$ & 0.032 & 14.9 \\
\hline $\begin{array}{l}\text { Sibling Correlation } \\
\text { (s.e.) } \\
\text { Family Component } \\
\text { (s.e.), } t \text {-statistic }\end{array}$ & $\begin{array}{l}0.156 \\
(0.044) \\
0.046 \\
(0.013)\end{array}$ & 0.065 & $\begin{array}{r}34.8 \\
\text { All }\end{array}$ & $\begin{array}{l}0.182 \\
(0.043) \\
0.036 \\
(0.009) \\
\text { Controls }\end{array}$ & $\begin{array}{l}0.067 \\
0.017 \\
\text { sed in T }\end{array}$ & $\begin{array}{r}26.8 \\
31.6 \\
\text { bles } 3\end{array}$ & $\begin{array}{l}0.153 \\
(0.023) \\
0.038 \\
(0.006) \\
\text { d } 6\end{array}$ & 0.062 & 28.8 \\
\hline $\begin{array}{l}\text { Sibling Correlation } \\
\text { (s.e.) } \\
\text { Family Component } \\
\text { (s.e.), } t \text {-statistic }\end{array}$ & $\begin{array}{l}0.121 \\
(0.047) \\
0.034 \\
(0.013)\end{array}$ & 0.099 & 45.0 & $\begin{array}{l}0.129 \\
(0.048) \\
0.025 \\
(0.009)\end{array}$ & 0.119 & 47.9 & $\begin{array}{l}0.122 \\
(0.024) \\
0.029 \\
(0.006)\end{array}$ & 0.093 & 43.1 \\
\hline $\begin{array}{l}\text { Sibling Correlation } \\
\text { (s.e.) } \\
\text { Family Component } \\
\text { (s.e.), } t \text {-statistic }\end{array}$ & $\begin{array}{l}0.111 \\
(0.047) \\
0.031 \\
(0.013)\end{array}$ & $\begin{array}{l}0.110 \\
0.040\end{array}$ & $\begin{array}{l}56.1 \\
\text { All Co }\end{array}$ & $\begin{array}{c}\text { ontrols Us } \\
0.129 \\
(0.048) \\
0.025 \\
(0.010) \\
\text { ntrols Use }\end{array}$ & $\begin{array}{l}0.028 \\
\text { in } T a b\end{array}$ & $\begin{array}{r}\text { les } 3 \\
48.0\end{array}$ & $\begin{array}{l}\text { and } 6 \\
0.115 \\
(0.024) \\
0.027 \\
(0.006) \\
\text { and } 6\end{array}$ & 0.100 & 46.6 \\
\hline $\begin{array}{l}\text { Sibling Correlation } \\
\text { (s.e.) } \\
\text { Family Component } \\
\text { (s.e.), } t \text {-statistic }\end{array}$ & $\begin{array}{l}0.109 \\
(0.047) \\
0.030 \\
(0.013) \\
\end{array}$ & 0.112 & 50.7 & $\begin{array}{l}0.123 \\
(0.049) \\
0.024 \\
(0.010) \\
\end{array}$ & 0.125 & 50.3 & $\begin{array}{l}0.112 \\
(0.024) \\
0.027 \\
(0.006) \\
\end{array}$ & 0.103 & 48.0 \\
\hline
\end{tabular}

\footnotetext{
$\downarrow$ gives the absolute decrease, $\% \downarrow$ gives the percentage decrease. Percentage decreases $>10 \%$ are shaded.
} 